\title{
Przekonania towarzyszące, ideologia i nauka
}

Rola, jaką religijne przekonania towarzyszące pełnią w kształtowaniu wiedzy, stała się przedmiotem wpływowego programu badawczego w Holandii za sprawą prac teologów Abrahama Kuypera (1837-1920) i Hermana Bavincka (1854-1921), filozofów Dirka Vollenhovena (1892-1978) i Hermana Dooyeweerda (1894-1977) oraz historyka nauki Reijera Hooykaasa (1906-1994). ${ }^{1}$ Owej roli nie odkryto w ramach badań historycznych. Pogląd jej dotyczący jest raczej normatywny, ugruntowany przez Kuypera i Bavincka w powszechnym charakterze odkupieńczego dzieła Chrystusa. Potrzeba odkupienia wiedzy wypływała z mającego długą tradycję poglądu, że na ludzką zdolność poznawczą wpłynął upadek w grzech. ${ }^{2}$ Przekonanie, że Chrystus posługuje się ludźmi jako narzędziami odkupienia, sprzyjało rozwojowi programu odkupienia kultury, takca.

Jitse M. van der Meer, Ph.D. — Redeemer University College, e-mail: jmvdm@redeemer.

(C) Copyright by Jitse M. van der Meer, Perspectives on Science and Christian Faith, Dariusz Sagan \& Filozoficzne Aspekty Genezy.

*Jitse M. van der Meer, „Background Beliefs, Ideology, and Science”, Perspectives on Science and Christian Faith 2013, vol. 65, no. 2, s. 87-103, http://www.asa3.org/ASA/PSCF/2013/ PSCF6-13vanderMeer.pdf (03.09.2016). Por. też archiwum czasopisma Perspectives on Science and Christian Faith: http://network.asa3.org/?page=PSCF. Za zgodą Autora i Redakcji z języka angielskiego przełożył: Dariusz SAGAN.

${ }^{1}$ Pierwotna wersja niniejszego artykułu opublikowana została 16 sierpnia 2010 na stronie Reformed Academic.

${ }^{2}$ Por. Peter Harrison, The Fall of Man and the Foundations of Science, Cambridge University Press, Cambridge 2007, s. 26-27. 
że wiedzy. Jedną z konsekwencji tego programu było to, że wiedza naukowa ma subiektywny składnik w postaci przekonań towarzyszących pełniących funkcję religijną, który to składnik pochodzi od podmiotu poznającego, nie wywodzi się zaś ze świata pozaludzkiego. ${ }^{3}$

Chociaż holenderski program badawczy zawitał na arenie międzynarodowej, to jednak nigdy nie został szeroko zaakceptowany. Pogląd o subiektywności nauki został jednak spopularyzowany w rezultacie dwu odkryć dokonanych niezależnie od szkoły Kuypera. Po pierwsze, zagadnienie to badane było także w Polsce, Wielkiej Brytanii i Stanach Zjednoczonych. ${ }^{4}$ Te pionierskie prace $\mathrm{w}$ dziedzinie historii i filozofii nauki oraz medycyny doprowadziły do uznania, że przekonania towarzyszące odgrywają rolę w kształtowaniu wiedzy naukowej. Przyczyniły się również do upadku pozytywizmu — poglądu, zgodnie z którym nie tylko wiedza naukowa, ale i cała wiedza jest zależna od tego, co można postrzegać zmysłami i uzasadnić rozumowo. Odkryć tych dokonano niezależnie od holenderskiej, neokalwinistycznej szkoły Kuypera i nie motywował ich religijny pogląd o odkupieniu wiedzy. Miały one podstawę w wiedzy historycznej i uzasadnienie w filozoficznej argumentacji, dzięki czemu spotkały się z powszech-

\footnotetext{
${ }^{3}$ Słowo o terminologii. Terminu ,przekonania towarzyszące” używać będę luźno jako synonimu presupozycji, światopoglądu, przekonania kontrolnego, ideologii i presumpcji. Ignoruję jakiekolwiek różnice między tymi terminami, ponieważ są one nieistotne dla mojego artykułu. Przekonanie towarzyszące rozumiem tu jako przekonanie, które jest potrzebne, zanim nawet zacznie się myśleć o pełnym zakresie różnych bytów, począwszy od Boga, a skończywszy na świecie fermionów, żab i uczuć.

${ }^{4}$ W Polsce: Ludwik FLECK, The Genesis and Development of a Scientific Fact, ed. T.J. Trenn and R.K. Merton, foreword by Thomas Kuhn, University of Chicago Press, Chicago 1979 (jest to pierwszy angielski przekład książki: Ludwik FLECK, Entstehung und Entwicklung einer wissenschaftlichen Tatsache. Einführung in die Lehre vom Denkstil und Denkkollektiv, Schwabe und Co., Verlagsbuchhandlung, Basel 1935 [przyp. tłum. — por. też polski przekład: Ludwik FLECK, Powstanie i rozwój faktu naukowego. Wprowadzenie do nauki o stylu myślowym i kolektywie myślowym, przeł. Maria Tuszkiewicz, w: Ludwik FLECK, Psychosocjologia poznania naukowego. Powstanie i rozwój faktu naukowego oraz inne pisma z filozofii poznania, red. Zdzisław Cackowski i Stefan Symotiuk, Wydawnictwo Uniwersytetu Marii-Curie Skłodowskiej, Lublin 2006, s. 31-163]). W Wielkiej Brytanii: Michael B. Foster, „The Christian Doctrine of Creation and the Rise of Modern Natural Science”, Mind 1934, vol. 43, s. 446-448; 1935, vol. 44, s. 439-466; 1936, vol. 45, s. 1-27; Michael Polanyi, Personal Knowledge: Towards a PostCritical Philosophy, University of Chicago Press, Chicago 1958. W Stanach Zjednoczonych: Thomas S. KuHn, Struktura rewolucji naukowych, przeł. Helena Ostromęcka i Justyna Nowotniak, Fundacja Aletheia, Warszawa 2001.
} 
niejszą akceptacją. Uznanie subiektywnego wymiaru wiedzy naukowej doprowadziło jednak niektórych do radykalnego zaprzeczenia, że wiedza o przyrodzie jest w ogóle możliwa (relatywizm). Niemniej ortodoksyjni chrześcijanie w Europie i Ameryce Północnej ochoczo przyjęli nową filozofię nauki, ponieważ przynajmniej potencjalnie - otwierała ona drogę dla roli religii w nauce. Szkoły Kuypera i Kuhna nawiązały współpracę. Niewielu chrześcijan zdawało sobie jednak sprawę z relatywizmu implikowanego szczególnie przez poglądy Kuhna.

Pogląd, że przekonania towarzyszące kształtują naukę, jest dziś ogólnie przyjęty, ale też różnie interpretowany. Na jednym końcu spektrum znajduje się szkoła socjologii nauki. Jej członkowie utrzymują, że prawda o przyrodzie w dużej mierze lub całkowicie zależna jest od wspólnej zgody naukowców (subiektywizm), nie zaś od samej przyrody. Na drugim krańcu mieszczą się niedobitki logicznych empirystów, czyli szkoła pozytywistyczna. Według logicznych empirystów prawda o przyrodzie odkrywana jest na podstawie obserwacji i dzięki rozumowi, co znaczy, że wynik zależy wyłącznie od badanego obiektu i właściwego zastosowania logiki (obiektywizm). Niektórzy chrześcijanie dołączyli do szkoły socjologii wiedzy nie dlatego, że chcą uznać społeczny wymiar zdobywania wiedzy, lecz z tego względu, że umożliwia im to arbitralne zaprzeczanie prawdziwości tych części nauki, które im zagrażają. Rozumują następująco: jeśli na treść teorii naukowych znacznie lub nawet całkowicie wpływają przekonania towarzyszące, to - dajmy na to - naturalizm i teizm grają na tym samym polu. Nie zdają sobie oni sprawy, że ten ruch jest bardzo kosztowny z perspektywy chrześcijańskiej. Po pierwsze, prawda o przyrodzie staje się w tym ujęciu w pełni zależna od przekonań grupy dzierżącej największą władzę. Po drugie - a jest to konsekwencja pierwszej uwagi — prawda nie zależy już od tego, co istnieje obiektywnie jako Boskie stworzenie. Czy możliwe jest uznanie roli przekonań towarzyszących w nauce (subiektywność), a zarazem uniknięcie czynienia z nich jedynego źródła wiedzy o przyrodzie (subiektywizm)?

Celem niniejszego artykułu jest dokonanie przeglądu niektórych odkrytych relacji między przekonaniami towarzyszącymi a naukowymi teoriami i wyjaśnieniami. Przyjmuję na wiarę, że - normalnie — przekonania towarzyszące potrzebne są do formułowania teorii w ramach nauk przyrodniczych. ${ }^{5}$ Przykła-

${ }^{5}$ Por. John H. Brooke, Science and Religion: Some Historical Perspectives, Cambridge 
dy podaję w kroku 3 poniżej. Argumentuję jednak, że nie stanowi to uzasadnienia dla popularnego mitu, że na naukę składa się zbiór arbitralnych opinii, co wyrażone jest w stwierdzeniu ,to tylko teoria”, lub że w nauce niepodzielnie panuje relatywizm. Swoją argumentację rozwijam w sześciu krokach.

\section{Krok 1: Religijna powinność teistów w nauce}

Dwa z mniej pożądanych zastosowań przekonań towarzyszących to promowanie relatywizmu i zniekształcanie wiedzy naukowej. Postmodernistyczni relatywiści przeczą temu, że da się uzyskać trwałą wiedzę o przyrodzie, gdyż zależne jest to od przekonań utrzymywanych w danym czasie. Punktem wyjściowym reakcji na takie nadużywanie przekonań towarzyszących musi być pogląd, że każdy uczony wierzący $\mathrm{w}$ istnienie niezależnej od umysłu rzeczywistości ma moralny obowiązek rozpoznawania i unikania relatywizmu oraz zniekształceń. Większość naukowców, bez względu na swoje preferencje religijne, przyjmuje tę odpowiedzialność i staje na stanowisku krytycznego realizmu. To znaczy wierzą oni, że naukowa wiedza o przyrodzie kształtowana jest przez obiekty przyrodnicze oraz przez przekonania naukowców na ich temat, przy czym ci ostatni mają krytyczne podejście do tych przekonań. Wielu naukowców motywuje pragnienie zachowania odpowiedzialności społecznej i pracy dla dobra wspierającej ich społeczności. Niewielu chce spędzić całe życie, usiłując zrozumieć coś, co nie istnieje.

Teiści wierzą, że Bóg stworzył obiektywnie istniejącą rzeczywistość. Pod tym względem są oni realistami. To przekonanie zapewnia im dodatkowy powód do przyjęcia obowiązku prowadzenia uczciwych badań przyrody. Wielbienie Boga w jego dziełach stanowi ich religijną powinność. Nie można tego robić, jeżeli zaprzecza się, że ludzie mają dostęp do stworzenia. Taki pogląd utrzymywany jest przez tych, którzy uważają, że wiedza o przyrodzie to wyłącznie konstrukcja umysłowa, a prawdę osiąga się, gdy wszystkie elementy tej konstrukcji są wzajemnie spójne (antyrealiści).

University Press, Cambridge 1991; John H. Brooke, Margaret J. Osler, and Jitse M. van DER MeER (eds.), Science in Theistic Contexts: Cognitive Dimensions, University of Chicago Press, Chicago 2001. 
Naukowi realiści nie przeczą, że w próby zrozumienia przyrody uwikłane są ludzkie przekonania, podkreślają jednak, że to rzeczywistość rozstrzyga, czy jakieś przekonanie uzyska status wiedzy. Co więcej, naukowcy — będący teistami lub nie - nie różnią się od innych ludzi, gdyż oni także popełniają błędy i nie zawsze odnoszą sukcesy. Chrześcijanie mają dodatkowe powody do zachowania wrażliwości na niedoskonałość wiedzy, ponieważ uznają ją za konsekwencję swojej ograniczoności i życia w świecie dotkniętym przez Upadek. Dlatego zarówno naukowcy chrześcijańscy, jak i niechrześcijańscy najczęściej są krytycznymi realistami. ${ }^{6}$ Wrażliwość chrześcijan na niebezpieczeństwo oszukiwania samych siebie to dar umożliwiający bycie dobrymi naukowcami. To jednak nie wystarczy. Ochronę przeciwko zniekształceniom powodowanym w nauce przez przekonania towarzyszące zapewniają różne kryteria. Jednym z nich jest zbieżność różnych linii danych empirycznych prowadzących do tego samego wyjaśnienia lub teorii. Przejdziemy teraz do omówienia tego kryterium.

\section{Krok 2: Niezależne linie danych empirycznych}

Teoria lub wyjaśnienie potwierdzane przez dane zgromadzone przez różnych niezależnych uczonych są lepiej chronione przed zniekształceniem niż te potwierdzane przez dane zebrane przez jednego uczonego. To kwestia zdrowego rozsądku. Agencje prasowe najbardziej ufają spójnym sprawozdaniom, które mają niezależne potwierdzenie. Gdy różne sprawozdania o jakimś zdarzeniu są ze sobą zgodne, niezależnie od sprawozdawców, to uznaje się je za prawdziwe. Podobnie pacjenci z większą ufnością decydują się na leczenie medyczne, gdy druga opinia jest zgodna z pierwszą. Kiedy różni lekarze niezależnie stawiają tę samą diagnozę, wskazując tę samą przyczynę, mówi się, że ustalają prawdziwa przyczynę choroby. Zasada stosowana w takich przypadkach głosi, że jeżeli to

\footnotetext{
${ }^{6}$ Por. np. Ian G. Barbour, „Commentary on Theological Resources from the Physical Sciences”, Zygon 1966, vol. 1, s. 29 [27-30]; Ian G. BARBouR, „Theology and Physics Forty Years Later”, Zygon 2005, vol. 40, s. 508 [507-512]; John Polkinghorne, „The Metaphysics of Divine Action”, w: Robert John Russell, Nancey Murphy, and Arthur Peacocke (eds.), Chaos and Complexity: Scientific Perspectives on Divine Action, Vatican Observatory Publications - The Center for Theology and Natural Sciences, Vatican City State - Berkeley, California 1997, s. 148 [147-156]. Na temat historii pojęcia krytycznego realizmu por. Andreas Losch, „On the Origins of Critical Realism”, Theology and Science 2009, vol. 7, s. 85-106.
} 
samo zdarzenie raportowane jest przez różnych dziennikarzy lub te same symptomy określane są przez różnych lekarzy, to ich twierdzenia są prawdziwe. Nie są bowiem zależne od osób, które je wygłaszają, lecz odpowiadają rzeczywistości. Wyrażenie „niezależne linie danych empirycznych” odnosi się do tego, że treść twierdzeń nie zależy od tego, kto je wygłasza.

Zasada niezależnych linii danych empirycznych ma zastosowanie również w bardziej złożonych okolicznościach, kiedy zamiast po prostu widzieć to samo, dwaj dziennikarze widzą różne rzeczy, ale wnioskują o tej samej przyczynie. Podobnie dwóch lekarzy może wywnioskować tę samą przyczynę choroby $\mathrm{z}$ dwu różnych zbiorów obserwacji. Na przykład psychiatra może uznać, że przyczyną bezsenności i depresji jest nienormalnie słaba aktywność tarczycy. Przyrost wagi i nienormalnie niski poziom tyroksyny może być przypisany przez radiologa niedoczynności tarczycy. Kiedy tak się dzieje, uważa się to za mocniejsze potwierdzenie istnienia wnioskowanej przyczyny — wadliwego funkcjonowania tarczycy - niż w naszym prostszym przykładzie. W prostym przypadku dwóch dziennikarzy raportuje tę samą obserwację; w złożonym dwóch lekarzy nie tylko wnioskuje o tej samej przyczynie na podstawie różnych obserwacji, ale i dokonuje obserwacji przy użyciu innych metod. Są to dwie różne linie danych empirycznych obserwowanych przez dwóch różnych ludzi, które wskazują na tę samą przyczynę. Innymi słowy, istnienie przyczyny, choć się o niej wnioskuje, jest niezależne nie tylko od wnioskujących osób, ale też od różnic między tym, co jest obserwowane, oraz od metod, za pomocą których dokonywane są obserwacje.

Ten złożony przypadek jest analogiczny do tego, co rozumie się przez niezależne linie danych empirycznych w nauce. Dostrzegam trzy powody, dla których przekonania towarzyszące przedstawicieli współczesnych nauk przyrodniczych nie prowadzą do łatwego zniekształcania interpretacji danych w ramach teorii i wyjaśnień (od tej chwili dla skrótu mówić będę tylko o „wyjaśnieniach”). Po pierwsze, liczba uczonych dokładających fragmenty układanki jest duża. Poniżej podam przykłady uczonych, którzy doszli do tego samego wyjaśnienia pomimo utrzymywania wzajemnie wykluczających się przekonań towarzyszących. Pokazuje to, że ich osobiste przekonania towarzyszące nie muszą zniekształcać wyjaśnień. 
Po drugie, gdy dane nie są zbieżne, nauka dysponuje standardowymi sposobami korekcji zniekształceń wyjaśnień. W takich sytuacjach poszczególni naukowcy mogą być zmuszeni do ponownego rozważenia sposobu, w jaki ich osobiste przekonania towarzyszące zostały wprowadzone do nauki. Dlatego, wziąwszy pod uwagę oba te powody, zbieżność danych prowadzących do tego samego wyjaśnienia jest najbardziej prawdopodobna, jeśli to wyjaśnienie jest poprawne. Istnieje możliwość, że wszyscy członkowie jakiejś społeczności badawczej zniekształcają dane $\mathrm{w}$ tym samym kierunku przez wprowadzanie tych samych przekonań towarzyszących. Jeżeli te poszczególne przekonania towarzyszące są niezależne od siebie, to przez wzgląd na wspólnotowy charakter badań prawdopodobieństwo losowego przyjęcia tego samego przekonania towarzyszącego jest bardzo małe. Pomimo tego małego prawdopodobieństwa członkowie społeczności badawczej mogą podzielać dowolne przekonania towarzyszące, jakie cechują ich społeczność lub tradycję badawczą, choćby wyłącznie dlatego, że mają takie samo wykształcenie. W procesie edukacji wpojono im przekonania towarzyszące cechujące daną społeczność badawczą, które mogą zniekształcać ich badania.

Trzeci powód, dla którego przekonania towarzyszące niekoniecznie zniekształcają wyjaśnienia i teorie, dotyczy takich właśnie wspólnotowo zniekształcających przekonań towarzyszących, a także tego, dlaczego można je wykluczyć z nauki. Przez wzgląd na to, że formułowanie jakiegoś wyjaśnienia może zająć dużo czasu, formujący je uczeni mogli żyć w różnych epokach, a więc należeć do różnych tradycji badawczych. Gdy dwie oddzielone w czasie tradycje badawcze prowadzą do tych samych wyjaśnień, można mieć większą pewność, że wyjaśnienia te są słuszne. Stało się tak, kiedy fizycy kwantowi zdali sobie sprawę, że klasyczna fizyka newtonowska nadal zachowuje zasadność jako szczególny przypadek fizyki kwantowej. To samo dotyczy uczonych żyjących w tej samej epoce i należących do różnych szkół myślenia. W historii biologii uczeni należący do mechanistycznej i witalistycznej szkoły myślenia ostatecznie doszli do tego samego poglądu, zgodnie z którym organizmy są jak maszyny mogące wyznaczać swoje własne cele. ${ }^{7}$ Wcześniejsze odmiany mechanicyzmu zakładały, że cel jest narzucany z zewnątrz, podczas gdy wcześniejsze odmiany

\footnotetext{
${ }^{7}$ Por. Charles T. Wolfe, „Teleomechanism Redux?: Functional Physiology and Hybrid Models of Life in Early Modern Natural Philosophy”, Gesnerus 2014, vol. 71, no. 2, s. 290-307.
} 
witalizmu interpretowały cel jako niematerialną siłę. Można więc wierzyć w słuszność wyjaśnienia, do którego niezależnie doszli uczeni należący do dwu społeczności, które uznawano za wzajemnie się wykluczające.

Wyjaśnię, dlaczego zarówno osobiste, jak i wspólnotowe przekonania towarzyszące są otwarte na krytykę (kroki 3 i 4). Najpierw przyjrzyjmy się jednak przykładom zbieżności niezależnych linii danych empirycznych prowadzących do tego samego wyjaśnienia w naukach przyrodniczych. Na początek rozpatrzymy przykłady z fizyki, koncentrując się na wkładzie Galileusza, Keplera, Newtona i Laplace'a do teorii mechaniki. ${ }^{8}$ Galileusz (1564-1642) opisał paraboliczną drogę pocisku oraz relację między prędkością, czasem a odległością przebytą przez ciało spadające ruchem jednostajnie przyspieszonym. Kepler (1571-1630) sformułował matematyczne prawa ruchu planet. Izaak Newton (1643-1727) połączył osiągnięcia Galileusza i Keplera i rozwinął je w postać trzech praw ruchu, które po raz pierwszy ogłosił drukiem 5 lipca 1687 roku w dziele Philosophiae Naturalis Principia Mathematica [Matematyczne zasady filozofii przyrody]. ${ }^{9}$ Pierwsze prawo stwierdza, że każde ciało pozostaje w stanie spoczynku lub porusza się ruchem jednostajnym, czyli ruchem ze stałą prędkością po linii prostej, chyba że zmianę tego stanu wymuszą wywarte na nie siły. Znaczy to, że przy braku siły wypadkowej środek masy ciała albo znajduje się w spoczynku, albo porusza się ze stałą prędkością. Drugie prawo głosi, że ciało o masie $m$ poddane sile $\boldsymbol{F}$ doznaje przyspieszenia $\boldsymbol{a}$, które ma ten sam kierunek, co przyłożona siła, oraz wielkość, która jest wprost proporcjonalna do siły i odwrotnie proporcjonalna do masy, co wyraża się wzorem $\boldsymbol{F}=m \boldsymbol{a}$. Inaczej mówiąc, całkowita siła przyłożona do ciała jest równa pochodnej pędu liniowego ciała względem czasu. Wreszcie, trzecie prawo wskazuje, że wzajemne siły między dwoma ciałami są równe, przeciwnie skierowane i współliniowe. Znaczy to, że gdy jedno ciało wywiera siłę $\boldsymbol{F}$ na drugie ciało, to drugie ciało wywiera siłę $-\boldsymbol{F}$ na pierwsze. $\boldsymbol{F}$ i $-\boldsymbol{F}$ mają równą wielkość i przeciwny kierunek. Prawo to niekiedy nazywane jest prawem akcji-reakcji, gdzie $\boldsymbol{F}$ to ,akcja”, zaś $-\boldsymbol{F}$ — ,reakcja”.

Newton posłużył się swoimi trzema prawami do wyjaśnienia ruchu wielu obiektów i układów fizycznych (łącznie z tymi, które badali Galileusz i Kepler),

\footnotetext{
${ }^{8}$ Jestem wdzięczny Arnoldowi Sikkemie za pomoc w opracowaniu tego przykładu.

${ }^{9}$ Por. http://csep10.phys.utk.edu/astr161/lect/history/newtongrav.html.
} 
jak również do wytłumaczenia upadku jabłka z drzewa. ${ }^{10} \mathrm{Na}$ przykład w trzeciej księdze swojego dzieła Newton pokazał, że te prawa ruchu, w połączeniu z jego prawem powszechnego ciążenia $\left(F=G m_{l} m_{2} / R^{2}\right.$ lub $\boldsymbol{F}=m \boldsymbol{g}$ dla Ziemi), wyjaśniają sformułowane przez Keplera prawa ruchu planet. Następnie do swojego unifikującego ujęcia Newton dołączył zaoferowane przez Galileusza opisy parabolicznej drogi pocisku oraz relacji między prędkością, czasem a odległością przebytą przez ciało spadające ruchem jednostajnie przyspieszonym. Wreszcie, matematyczny opis orbit planet w mechanice newtonowskiej został uproszczony przez Lagrange'a (1736-1813), zaś Pierre-Simon Laplace (17491827) podał ich genetyczne wyjaśnienie. Laplace postulował, że na początku Układ Słoneczny był mgławicową chmurą, z której stopniowo oddzieliły się pierścienie, a każdy z nich uległ z kolei skupieniu, tworząc planety. To wyjaśniało, dlaczego planety poruszają się w przybliżeniu w tej samej płaszczyźnie i w tym samym kierunku. Wiele osób uznało, że owo uproszczenie implikuje, że Boskie poprawki nie są już konieczne, aby utrzymać planety na ich orbitach, jak sądził Newton. Lagrange i Laplace wykazali wspólnie, że Układ Słoneczny może stabilizować się sam.

Zwróćmy uwagę, że Galileusz był wyznania rzymskokatolickiego, Kepler — protestanckim platonikiem, Newton - unitariańskim deistą, a Laplace ateistą. Pomimo tych odmiennych osobistych religijnych i metafizycznych przekonań towarzyszących mieli oni wkład w rozwój mechaniki. Przywiązanie do platonizmu skłoniło Keplera do oczekiwania, że orbity planet są doskonale kołowe. Jak wiadomo, ustalenie, że mają kształt eliptyczny, zajęło mu ponad trzydzieści lat. Laplace był ateistą, a jego hipoteza mgławicowa miała zastąpić odwołania do celu i projektu działaniem praw fizycznych. Zauważmy jednak, że ta motywacja nie odgrywa żadnej roli, jeśli chodzi o ustalenie prawdy, ta bowiem zależy od faktów dotyczących naszego Układu Słonecznego. Uzmysławia to, że rzeczywistość fizyczna opiera się zniekształceniu przez przekonania towarzyszące tych poszczególnych naukowców. $Z$ drugiej strony podzielali oni pogląd, że Wszechświat jest maszyną. To jednak tylko przesuwa pytanie o to, jaki mogli mieć oni wkład do teorii mechaniki, z poziomu teorii na poziom przekonania towarzyszącego. Wyjaśnienia wymaga zaś to, jak mogli podzielać mechanistyczne

\footnotetext{
${ }^{10}$ Por. http://news.cnet.com/8301-1023 3-10438960-93.html (07.09.2016).
} 
spojrzenie na kosmos, skoro mieli odmienne przekonania towarzyszące. Objaśnię to w kroku 3.

Teraz rozważymy bardziej techniczny przykład zbieżności różnych linii danych prowadzących do tego samego wyjaśnienia we współczesnej fizyce. ${ }^{11}$ Zgodnie z teorią Słońce zasilane jest energią syntezy jądrowej. Skąd to wiemy? Twierdzenie to można nazwać teorią wyższego rzędu, która obejmuje różne niepowiązane modele i teorie. Z kolei każdy model i każda teoria wykorzystuje różne modele i teorie niższego rzędu, które wszystkie potwierdzane są przez zbieżne linie danych. W związku z tym nie tylko jedna teoria potwierdzana jest przez zbieżność różnych linii danych. Istnieje cała sieć takich zbieżnych linii. $\mathrm{Na}$ najbardziej bezpośrednim poziomie eksperymentalnym bogactwo danych zapewnia mocne potwierdzenie ograniczonej liczbie teorii i modeli. Wszystkie z dużą wyrazistością potwierdzają teoretyczne twierdzenie, że energia Słońca wytwarzana jest przez syntezę jądrową. Liczba naukowców, którzy uzyskali te wszystkie dane, sięga tysięcy. Ale to nie tylko liczba gwarantuje różnorodność przekonań towarzyszących. Naukowcy żyli również w różnych miejscach i czasach i w prawie każdym przypadku musieli się zmagać z niespodziewanymi wynikami, które spotykały się ze znacznym oporem społeczności naukowej jako takiej. Oto niektóre z tych danych.

1. Modele równowagi grawitacyjnej/radiacyjnej w gwiazdach, łącznie ze Słońcem, opierają się na:

- Newtonowskiej teorii grawitacji, która jest z dużą dokładnością potwierdzona przez obserwacje Układu Słonecznego oraz eksperymenty laboratoryjne.

- Wiedzy o masie i rozmiarze Słońca, które ustala się za pomocą pomiaru odległości, teorii grawitacji, trygonometrii, prędkości światła i długości roku. Z kolei prędkość światła zwykle mierzona jest zarówno w warunkach laboratoryjnych, jak i w szerszych partiach Układu Słonecznego, a także jest dobrze rozumiana dzięki klasycznej teorii elektromagnetyzmu oraz elektrycznym i magnetycznym własnościom próżni.

\footnotetext{
${ }^{11}$ Dziękuję Arnoldowi Sikkemie za opracowanie tego przykładu.
} 
- Teoretycznej wiedzy o ciśnieniu radiacyjnym opartej na teorii elektromagnetyzmu i Einsteinowskiej szczególnej teorii względności (umożliwiającej zrozumienie pędu cząstek światła) i potwierdzonej przez tysiące niezależnych eksperymentów.

2. Modele wnętrza Słońca potwierdzone przez heliosejsmologię i zgodne z warunkami koniecznymi do zachodzenia syntezy jądrowej.

3. Modele syntezy jądrowej zgodne $\mathrm{z}$ Einsteinowską szczególną teorią względności łączącą masę $\mathrm{z}$ energią; mówiąc ogólniej, chodzi o teorię cząstek o wysokich energiach. Obie teorie potwierdzone są przez tysiące niezależnych eksperymentów i miliardy niezależnych zderzeń analizowanych w akceleratorach cząstek na całym świecie.

4. Spójność z astrofizycznymi wyjaśnieniami obserwacji względnej ilości pierwiastków chemicznych w całym Wszechświecie dokonywanych za pośrednictwem analizy spektralnej gwiazd, materii międzygwiazdowej i galaktyk. Analiza spektralna polega na wykorzystaniu standardowych praktyk laboratoryjnych optyki falowej i sprawdzaniu emisji gazu oraz pochłaniania promieniowania elektromagnetycznego, które są dobrze rozumiane dzięki chemii kwantowej.

5. Spójność ze zmierzonym tempem detekcji neutrin ze Słońca, jak również z późniejszym eksperymentalnym potwierdzeniem oscylacji neutrin, co wyjaśniło anomalię, która pozostawała niewytłumaczona przez trzydzieści lat.

6. Spójność z szerokim zakresem zastosowań astrofizyki gwiazdowej, takich jak modele końcowych stanów gwiazd, w których synteza jądrowa gra dobrze rozumianą rolę nawet $\mathrm{w}$ ekstremalnych warunkach supernowych, wliczając $\mathrm{w}$ to produkcję neutrin.

Wiemy ponadto, że wyraźnie zawodzą wszystkie alternatywne modele naukowe (takie jak ten, który sugerował niegdyś, że Słońce jest zasilane procesami chemicznymi), które miały wyjaśniać obserwowaną wydajność energii promieniowania, stabilność, widmo, rezonanse i tak dalej.

Trzeci przykład zbieżności różnych linii danych prowadzących do tego samego wyjaśnienia pochodzi z geologii. Rozważymy teorię tektoniki płyt. Teoria ta wyjaśnia, jak ziemskie kontynenty utworzyły się przez rozdzielenie jednego kontynentu na części, które oddalały się od siebie, formując obecnie znane kon- 
tynenty. Omówię kilka niezależnych linii danych, w tym geometryczne dopasowanie przemieszczonych kontynentów (na przykład między Afryką Zachodnią a wschodnim wybrzeżem Ameryki Południowej), podobieństwo wieków skał i paleozoicznych skamieniałości w odpowiadających im warstwach skalnych między kontynentami, głębokie rowy w dnie oceanicznym, gdzie jedna płyta wchodzi pod drugą (synkliny), łańcuchy górskie pośrodku dna morskiego między kontynentami (grzbiety śródoceaniczne) oraz muszle na górskich szczytach, które znalazły się tam wskutek wyniesienia skorupy ziemskiej w strefach zderzeń.

Co więcej, przemieszczanie się dna morskiego wyjaśnia ruch kontynentów. Wzdłuż długości grzbietu śródoceanicznego nowa magma $\mathrm{z}$ ziemskiej głębi podnosi się i wypływa z otworów lub kominów hydrotermalnych, tworząc nową skorupę oceaniczną. ${ }^{12}$ Proces ten odpycha kontynenty od siebie oraz od grzbietu. Linie danych potwierdzających to wyjaśnienie obejmują między innymi datowanie radiometryczne, badania skamieniałości i ziemski magnetyzm. Wiek skał ustalany metodą datowania radiometrycznego jest podobny w znajdujących się w jednakowej odległości pasach skorupy symetrycznie rozmieszczonych na grzbiecie śródoceanicznym. Wiek skał rośnie wraz ze wzrostem odległości od grzbietu śródoceanicznego. Ponadto identyczne skamieniałości odkrywane są w pasach skorupy równoodległych od grzbietu. Wskazuje to, że jakiś konkretny pas skorupy miał podobną historię, jak odpowiadający mu pas skorupy znajdujący się po drugiej stronie grzbietu. Nie jest tylko tak, że po obu stronach grzbietu występują pasy i skamieniałości o tym samym wieku, ale i badania kierunków pola magnetycznego utrwalonego w skałach ujawniają istnienie pasów o podobnych kierunkach pola magnetycznego znajdujących się w jednakowej odległości po obu stronach grzbietu śródoceanicznego. Powyższa lista jest bardzo niekompletna, ale wystarczy do pokazania, że w tym wypadku istnieją niezależne linie danych empirycznych. ${ }^{13}$

\footnotetext{
${ }^{12}$ Por. film pokazujący komin hydrotermalny: www.ceoe.udel.edu/deepsea/level-2/geology/ vents.html.

${ }^{13} \mathrm{Z}$ większą ilością danych można zapoznać się na następujących stronach: http://en.wikipe dia.org/wiki/Plate_tectonics\#cite_ref-17 (07.09.2016); http://www.physicalgeography.net/fundam entals/10i.html (07.09.2016); http://www.visionlearning.com/library/module_viewer.php?mid=65 (07.09.2016); http://earthsci.org/education/teacher/basicgeol/platec/platec.html (07.09.2016).
} 
Ostatni przykład dotyczy zbieżności różnych linii danych prowadzących do tego samego wyjaśnienia w biologii. Teoria pochodzenia gatunków biologicznych ma kilka różnych niezależnych źródeł potwierdzenia. Na przykład wyniki badań historii ponad setki gatunków muszek owocowych na wyspach hawajskich wskazują na niezwykłą zgodność geologicznych, biologicznych i geograficznych linii danych. Geologiczne badania tektoniki płyt prowadzą do wniosku, że płyta pacyficzna porusza się na północny zachód nad nieruchomym gorącym punktem w jądrze Ziemi. Ten gorący punkt topi przemieszczającą się nad nim płytę, tworząc kolejno szereg wysp wulkanicznych. ${ }^{14}$ Dlatego oczekuje się $\mathrm{i}$ jest to potwierdzone - że najstarsza wyspa znajduje się na najbardziej wysuniętym na północny zachód końcu podmorskiego łańcucha górskiego - 2400 km od Hawajów, blisko Półwyspu Kamczackiego (Wschodnia Rosja). ${ }^{15}$ Dane dotyczące tektoniki płyt korelują $\mathrm{z}$ danymi na temat stosunku izotopów ${ }^{40} \mathrm{Ar} /{ }^{39} \mathrm{Ar}$, wskazującymi, że najstarsze wyspy, według datowania argonem, są też najmniejsze, to jest najbardziej zerodowane, i zgodnie $\mathrm{z}$ oczekiwaniami znajdują się na północnym zachodzie. Najmłodsze wyspy są największe i - jak przewidywano - znajdują się na południowym wschodzie (na przykład Hawaje).

Te dwie linie danych geologicznych są zgodne z trzema niezależnymi liniami danych biologicznych. Zasadniczo tę samą genealogię gatunków muszek owocowych ustalono na podstawie porównania cech morfologicznych, sekwencji DNA i mutacji chromosomalnych. Wreszcie, przyglądając się geograficznemu rozmieszczeniu różnych gatunków, widzimy, że filogenetycznie najmłodsze gatunki Drosophila występują na najmłodszych wyspach Archipelagu Hawajskiego, ponieważ zostały skolonizowane przez muszki owocowe jako ostatnie. ${ }^{16}$ Podsumowując, istnieje korelacja między historią mutacji w ich chromosomach,

\footnotetext{
${ }^{14}$ Por. http://en.wikipedia.org/wiki/Hawaiian_Islands (08.09.2016).

${ }^{15}$ Por. http://tiny.pl/gcszn (08.09.2016).

${ }^{16}$ Por. Hampton L. CARson, „Inversions in Hawaiian Drosophila”, w: C.B. Krimbas and J.R. Powell (eds.), Drosophila Inversion Polymorphism, CRC Press, Boca Raton, Florida 1992, s. 407-439 (por. też streszczenie tego tekstu: http://bio.illinoisstate.edu/kaedwar/HawaiianDroso phila/CarsonTree.htm); Patrick M. O'Grady et al., „Polytene Chromosomes as Indicators of Phylogeny in Several Species Groups of Drosophila", BMC Evolutionary Biology 2001, vol. 1, s. 1-6, http://www.biomedcentral.com/1471-2148/1/6 (08.09.2016).
} 
geograficznym rozmieszczeniem ich gatunków, następstwem czasowym, w jakim wyspy wzniosły się ponad poziom morza wskutek aktywności wulkanicznej, oraz kierunkiem dryfu kontynentów. Ten program badawczy, trwający od 1963 roku, obejmuje pięć niezależnych linii danych. Biorą w nim udział setki naukowców reprezentujących różne kultury z całego świata. Ich przekonania towarzyszące nie są znane, ale można mieć pewność, że taka międzynarodowa obsada żywi różne przekonania tego typu. Mimo to wszyscy ci naukowcy doszli do takiej samej rekonstrukcji historii naturalnej hawajskich muszek owocowych. Podobnie jak w poprzednich przykładach, ta zgodność jest prawdopodobnie gwarantowana przez szeroką zgodę w kwestii metodologii naukowej zarówno w sensie ogólnym, jak i w przypadku dyscyplin szczegółowych. Tak jak wcześniej, przesuwa to jednak pytanie, jak naukowcy mogą przyczynić się do ustalenia naturalnej historii hawajskich muszek owocowych, z poziomu teorii na poziom przekonań towarzyszących. Pytanie brzmi, jak mogli oni dojść do tej samej historii naturalnej pomimo różnych przekonań towarzyszących. Wyjaśnię to w kroku 3.

\section{Krok 3: Przekonania towarzyszące można oddzielić od wyjaśnień naukowych}

Co się dzieje, gdy różne linie danych nie zbiegają się i nie prowadzą do tego samego wyjaśnienia? Jest wiele czynników powodujących taką sytuację. Zignorujemy je wszystkie, aby skoncentrować się na możliwości, że powodem braku zbieżności jest zniekształcenie danych przez przekonania towarzyszące. Czy można temu przeciwdziałać? Logicznie rzecz biorąc, przekonanie towarzyszące funkcjonuje jako presupozycja teorii lub wyjaśnienia. Każde wyjaśnienie lub teoria presuponuje jedno lub więcej przekonań towarzyszących. W tej części argumentuję, że przekonania towarzyszące można logicznie oddzielić od wyjaśnień, które są przez nie wspierane. Kluczowe jest to, że przekonanie towarzyszące nie determinuje teorii. ${ }^{17}$ Powodem tego jest to, że nie istnieje żaden prosty konieczny (logiczny) związek między przekonaniem towarzyszącym - chrześcijańskim lub innym — a wyjaśnieniem naukowym. Przekonania towarzyszące

\footnotetext{
${ }^{17}$ Teoria lub wyjaśnienie może, ale nie musi determinować przekonania towarzyszącego.
} 
występują na innych poziomach ogólności. Przykłady, które omówię poniżej, dotyczą przekonań ostatecznych — przekonań towarzyszących funkcjonujących na najwyższym poziomie ogólności jako przekonania metafizyczne lub religijne. Moje wnioski mają zastosowanie również do przekonań towarzyszących niższego rzędu, które cechują szkoły myślenia lub tradycje badawcze.

\section{Samo przekonanie towarzyszące nie determinuje teorii}

Świadectwa na rzecz tezy, że przekonania towarzyszące można oddzielić od wyjaśnień naukowych, mają związek z tym, że wyjaśnienia wzajemnie sprzeczne można podciągnąc pod to samo teistyczne przekonanie towarzyszące. $\mathrm{Na}$ przykład przekonanie towarzyszące, zgodnie z którym Bóg stworzył zwierzęta mające cel - przykładowo cel rozmnażania się - ma co najmniej dwa wzajemnie wykluczające się wyjaśnienia (Rys. 1).

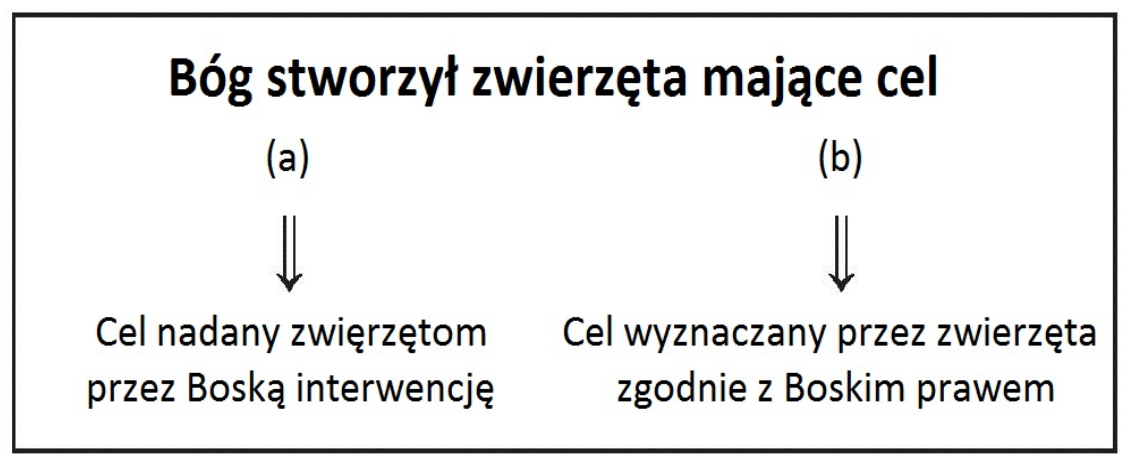

Rys. 1. Wzajemnie niezgodne teorie (a) i (b) można podciągnąć pod to samo przekonanie towarzyszące. Przekonanie towarzyszące, zgodnie z którym Bóg stworzył zwierzęta mające cel, można uszczegółowić na co najmniej dwa różne sposoby. (a) Dodanie hipotezy, że Bóg działa poprzez interwencje, sprawia, że celowa organizacja zwierząt jest bezpośrednio zależna od ciągłych Boskich interwencji. Wynika z tego, że organizmy uzyskują swoje cele bezpośrednio spoza siebie. (b) Dodanie hipotezy, że Bóg działa za pośrednictwem praw przyrody, prowadzi do uznania, że stworzył organizmy obdarzone zdolnością do wyznaczania własnych celów. To znaczy organizmy uzyskują swoje cele pośrednio spoza siebie. Bez hipotez uszczegóławiających przekonanie towarzyszące nie determinuje (nie pociąga za sobą) teorii. Teorie presuponują przekonanie towarzyszące. 
Jeżeli za tybingeńskim fizjologiem Carlem Friedrichem Kielmeyerem (1765-1844) dodamy hipotezę, że Bóg działa za pośrednictwem praw przyrody, to wynika z niej, że Bóg stworzył organizmy zdolne to wyznaczania własnych celów. Z drugiej strony, jeśli za francuskim zoologiem Georgesem Cuvierem (1769-1832) przyjmiemy, że cele organizmów są bezpośrednio zależne od Boga, to wynika $\mathrm{z}$ tego, że organizmy uzyskały swoje cele spoza siebie, gdy były stwarzane. Tak więc $\mathrm{w}$ połączeniu $\mathrm{z}$ podzielanym przekonaniem towarzyszącym, zgodnie z którym Bóg stworzył organizmy mające cel, różne uszczegóławiające założenia dotyczące sposobu działania Boga w świecie — za pośrednictwem praw przyrody lub poprzez interwencje - prowadzą do różnych wyjaśnień celowego zachowania zwierząt. Celowe zachowanie generowane jest wewnętrznie przez organizm, jeżeli Bóg stwarza za pośrednictwem praw przyrody, albo zewnętrznie, jeśli organizmy zostały stworzone bez tej wewnętrznej zdolności. Oba wyjaśnienia logicznie presuponują przekonanie towarzyszące mówiące, że Bóg stworzył organizmy mające cel. Samo to przekonanie towarzyszące nie determinuje (nie pociąga za sobą) jednak żadnego z tych wyjaśnień.

Przekonanie towarzyszące jest ogólniejsze od założenia uszczegóławiającego, które różni się od przekonania towarzyszącego tym, że je uszczegóławia. Tak powstałe wyjaśnienie jest mniej ogólne niż przekonanie towarzyszące, od którego się wywodzi. Powodem, dla którego dwa wzajemnie wykluczające się wyjaśnienia mogą wywodzić się z tego samego przekonania towarzyszącego na temat Stwórcy, są różne założenia uszczegóławiające dotyczące tego, jak Bóg działa w świecie. Gdyby teorie były determinowane przez przekonania towarzyszące, to pojedyncza teoria skojarzona byłaby tylko z jednym takim przekonaniem bez udziału założeń uszczegóławiających.

Drugi przykład wzajemnie wykluczających się wyjaśnień podlegających temu samemu przekonaniu towarzyszącemu pochodzi z astronomii. Izaak Newton (1642-1727) dostarczył matematyczny opis orbit planet. Opis ten implikował, że dana planeta stopniowo zbacza ze swojej orbity. Newton sądzil, że aby temu zapobiec, Bóg musi od czasu do czasu interweniować w celu poprawienia orbity. Gottfried Wilhelm Leibniz (1646-1716) zarzucał, że urąga to doskonałości Boga. Bóg jest wszechwiedzący, a więc przewidziałby ten problem i stworzył układ planetarny niewymagający interwencji. Chodzi o to, że zarówno Newton, jak i Leibniz wierzyli, że Bóg jest Stwórcą kosmosu. Zgadzali się, że 
Bóg jest wszechmocny, wszechwiedzący, dobry i wolny. Nie zgadzali się jednak w kwestii potrzeby Boskiej ingerencji w układ planetarny, ponieważ podkreślali wagę innych atrybutów Boga (Rys. 2).

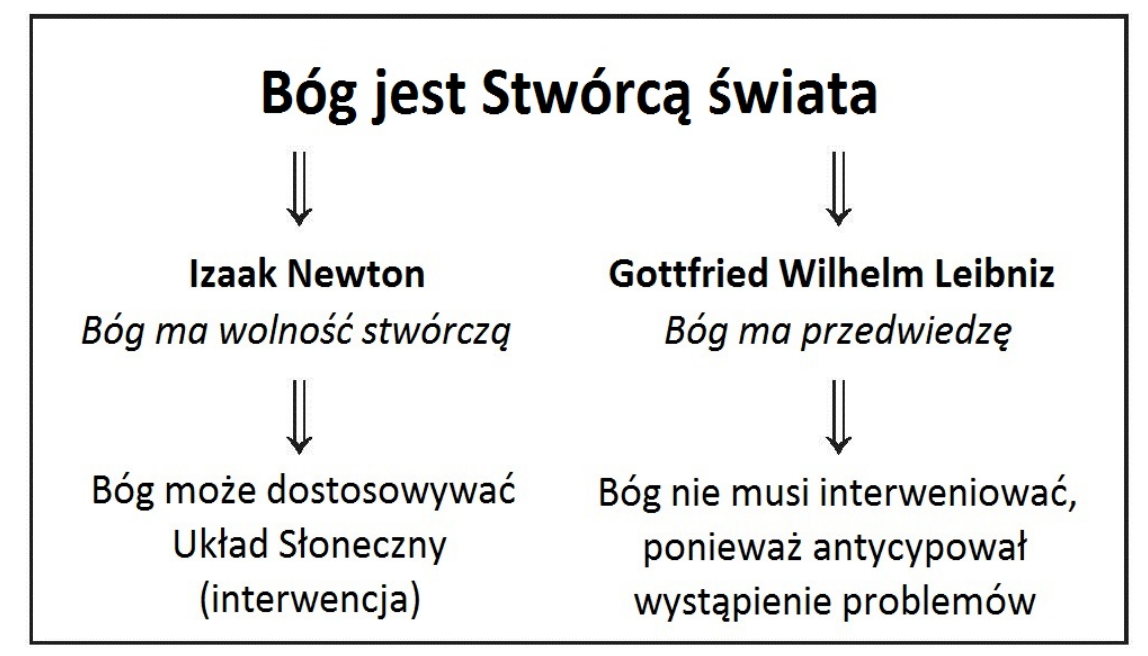

Rys. 2. Newton i Leibniz nie zgadzali się w kwestii potrzeby Boskiej ingerencji w układ planetarny, ponieważ żywili inne poglądy na to, jak Boska wszechmoc przejawia się w działaniu Boga.

Newton kładł nacisk na Boską wszechmoc. Oznaczało to, że Bóg może stworzyć, co tylko zechce, zaś Newton dodał założenie uszczegóławiające, że Bóg działa w świecie poprzez interwencje. Natomiast Leibniz podkreślał Boską wszechwiedzę. Bóg, który wie wszystko, antycypował wszystkie następstwa tego, co chciał stworzyć, zanim to stworzył. Późniejsze poprawki nie były więc potrzebne. Leibniz dodał założenie uszczegóławiające, że Bóg stworzył świat tak doskonały, że funkcjonuje $\mathrm{w}$ zgodzie $\mathrm{z}$ własnymi prawami. ${ }^{18}$ Tym samym Leibniz odrzucał uszczegóławiające założenie Newtona.

\footnotetext{
${ }^{18}$ Por. Gottfried Wilhelm LeibnIz, „A New System of the Nature and Communication of Substances, and of the Union of the Soul and Body (1695)", w: G.W. Leibniz: Philosophical Essays, trans. and ed. Roger Ariew and Dan Garber, Hackett, Indianapolis, Indiana 1989, s. 143-144 [138$145]$.
} 
I tym razem dwa wzajemnie wykluczające się wyjaśnienia zachowania planet można podciągnąć pod to samo teistyczne przekonanie towarzyszące. Każde wyjaśnienie presuponuje przekonanie towarzyszące, że Bóg stworzył świat. Samo to przekonanie nie determinuje jednak wyjaśnienia. Różnica między tymi dwoma wyjaśnieniami zachowania planet polega na tym, że Newton i Leibniz kładli nacisk na inne atrybuty Stwórcy - wolność stwarzania lub przedwiedzę o tym, co się stanie z tworami aktu stwórczego. To dlatego dodali różne założenia uszczegóławiające do wspólnego im przekonania towarzyszącego.

Powyższe dwa przykłady pokazują, że wzajemnie niespójne wyjaśnienia w biologii i fizyce można podciągnąć pod te same religijne przekonania towarzyszące poprzez dodanie różnych założeń uszczegóławiających na temat Boskiego działania. Same przekonania towarzyszące nie determinują wyjaśnień, lecz wymagają ponadto dołączenia hipotezy uszczegóławiającej. Przy zmianie hipotezy uszczegóławiającej przekonanie towarzyszące może determinować inne wyjaśnienie. Dlatego, jeśli jakieś przekonanie towarzyszące podejrzewa się o rozbijanie zbieżności różnych linii danych prowadzących do tego samego wyjaśnienia z powodu zniekształcania danych, to można temu przeciwdziałać dzięki zmianie hipotezy uszczegóławiającej. Zachodzi natomiast relacja odwrotna - wyjaśnienie determinuje przekonanie towarzyszące. Nie ma to jednak znaczenia, jeśli chodzi o cel eliminowania zniekształceń danych przez przekonania towarzyszące.

Istnieje więcej świadectw wskazujących, że przekonania towarzyszące można oddzielić od wyjaśnień naukowych. W poprzednich dwóch przykładach wzajemnie niespójnie wyjaśnienia podpadały pod to samo religijne przekonanie towarzyszące. Możliwa jest jednak również sytuacja odwrotna. Różne przekonania towarzyszące mogą funkcjonować jako presupozycje tego samego wyjaśnienia. To znaczy to samo wyjaśnienie można podciągnąć pod wzajemnie wykluczające się przekonania towarzyszące poprzez dodanie do nich różnych założeń uszczegóławiających. Nie mogłoby to mieć miejsca, gdyby przekonania towarzyszące determinowały wyjaśnienia. Dobrym przykładem jest teleomechanicyzm - teoria, zgodnie z którą organizmy są maszynami wyznaczającymi sobie własne cele. Chrześcijański teleomechanicyzm to przekonanie towarzyszące utrzymywane przez wielu dziewiętnastowiecznych biologów niemieckich. Uważali oni, że organizmy zostały zaprojektowane przez Boga, który wyposażył je 
w zdolność do wyznaczania własnych celów. Zarówno materializm, jak i chrześcijaństwo zostały uszczegółowione tak, aby dać poparcie teorii, że organizmy wyznaczają własne cele (Rys. 3).

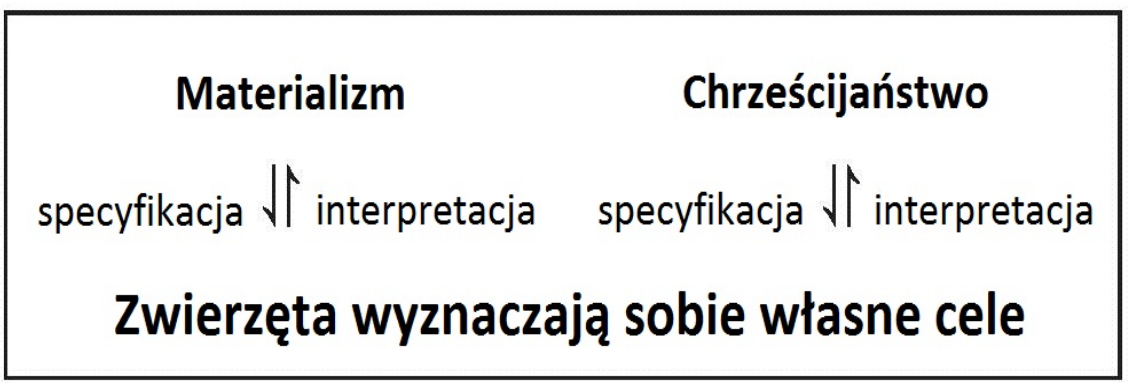

Rys. 3. Ta sama teoria podciągnięta pod wzajemnie wykluczające się przekonania towarzyszące. Teoria nie determinuje przekonań towarzyszących (materializm i chrześcijaństwo nie determinują teorii).

Materialiści, którzy uważają, że celowe zachowanie organizmów jest rzeczywiste, a nie tylko pozorne, uszczegółowili swoje przekonanie towarzyszące przez dodanie hipotezy, że materia ma zdolność do tworzenia celowo działających organizmów. Chrześcijanie uszczegółowili swoją wiarę w Stwórcę, dodając hipotezę, że Bóg zaprojektował organizmy ze zdolnością do wyznaczania własnych celów. Innymi słowy, ideę celowego działania organizmów można wywieść zarówno z niereligijnych, jak i religijnych przekonań towarzyszących przez dodanie różnych hipotez uszczegóławiających. Dlatego teoria, że organizmy wyznaczają własne cele, jest logicznie niezależna od przekonania towarzyszącego, Bóg stworzył świat dla jakiegoś celu. Mógł On narzucić cel poprzez interwencję. Przejście w przeciwnym kierunku od teorii do przekonania towarzyszącego oznacza, że celowość obserwowaną w organizmach można interpretować religijnie i niereligijnie. Logicznie rzecz biorąc, przykład ten jest identyczny w stosunku do poprzednich w tym względzie, że same dwa przekonania towarzyszące - materializm i chrześcijaństwo - nie determinują teorii, zgodnie z którą organizmy wyznaczają sobie własne cele. Dopiero przekonanie towarzyszące $\mathrm{w}$ połączeniu z założeniem uszczegóławiającym pociąga za sobą tę teorię. 
Przykład ten różni się jednak od wcześniejszych pod tym względem, że teoria nie presuponuje żadnego $\mathrm{z}$ tych dwu przekonań towarzyszących.

Przykłady te pokazują, że samą teorię można podciągnąć pod wzajemnie niezgodne przekonania towarzyszące. To również potwierdza moją tezę, że przekonania towarzyszące można oddzielić od wyjaśnień naukowych dzięki zmianie założeń uszczegóławiających. Podobnie jak wcześniej, wniosek ten ma zastosowanie do przekonań towarzyszących na każdym poziomie ogólności. Skoro przykłady te dotyczą przekonań religijnych, to wniosek ten obejmuje także najwyższy poziom ogólności czy przekonania ostateczne.

\section{Wniosek doraźny}

Poszczególne przekonanie filozoficzne lub religijne, funkcjonujące na zapleczu nauki, nie może determinować lub pociągać za sobą jakiegoś poszczególnego wyjaśnienia w prosty sposób, ponieważ wyjaśnienie połączone jest $\mathrm{z}$ wieloma innymi założeniami uszczegóławiającymi. Przykłady pokazują, że - logicznie rzecz biorąc - wyjaśnienie można oddzielić od przekonania towarzyszącego. Jest to możliwe, gdyż przekonania towarzyszące o wysokim poziomie ogólności muszą zostać uszczegółowione, aby mogły podlegać testom. Taką specyfikację uzyskuje się poprzez dodanie hipotez uszczegóławiających do przekonania towarzyszącego. Skoro hipotezy uszczegóławiające można zastąpić, to przekonania towarzyszące po prostu nie determinują wyjaśnień zjawisk przyrodniczych. To chroni przed relatywizmem naukowym, który byłby implikowany, gdyby religijne i inne przekonania towarzyszące determinowały wyjaśnienia naukowe. Różne religijne przekonania towarzyszące można uzgodnić z tymi samymi obserwacjami i wyjaśnieniami dzięki dodaniu różnych hipotez uszczegóławiających.

Wynika z tego, że presupozycje biblijne nie determinują pewnego rodzaju nauki o unikatowej chrześcijańskiej treści. Różnica między dwoma rodzajami nauki zostaje ograniczona do przekonań towarzyszących naukowców. Wniosek ten znajduje potwierdzenie w istnieniu szkół myślenia w nauce, które żywią odmienne przekonania towarzyszące. W fizyce istnieją różne interpretacje fizyki kwantowej. W biologii gradualizm i koncepcja przerywanej równowagi reprezentują różne szkoły teorii ewolucji. W geologii uniformitaryzm i katastrofizm 
stanowiły różne interpretacje ziemskiej historii. Uczeni należący do różnych tradycji mają odmienne przekonania towarzyszące, ale dysponują tymi samymi obserwacjami i wyjaśnieniami. Podobnie chrześcijanie i niechrześcijanie mogą dzielić te same obserwacje i wyjaśnienia, ponieważ nauka zakorzeniona jest w obiektywnej rzeczywistości.

I przeciwnie, jak pokazuje przypadek teleomechanicyzmu, poszczególne wyjaśnienie w nauce może, ale nie musi presuponować jakiegoś poszczególnego światopoglądu lub filozofii. Niestety, złożoność związków między przekonaniami towarzyszącymi a wyjaśnieniami, jak również powiązana z nią złożoność wysiłków oddzielania ideologii od nauki, zapewnia przykrywkę tym, którzy posuwają się do nadużywania teorii, by propagować ideologie. Kaznodzieje religii świeckiej, tacy jak Carl Sagan, Richard Dawkins i Daniel Dennett, nie oddają dobrej przysługi rzeczowej nauce, propagując w jej imię agresywny antychrześcijański ateizm. Chrześcijanie muszą nauczyć się dostrzegać te przypadki nadużywania nauki, jeśli nie chcą wylać dziecka nauki z kąpielą ideologii. W przeciwnym razie zaprzepaszczą nadane im przez Boga powołanie do wielbienia Stwórcy w Jego stworzeniu. Trzeźwi ateiści potrafią dostrzec tę farsę, o czym świadczą głosy krytyczne względem Richarda Dawkinsa. Kanadyjski filozof i sceptyk religijny Michael Ruse skomentował ostatnio: ,Jestem oburzony marną jakością argumentacji Dawkinsa, Dennetta, Hitchensa i wszystkich innych w tej grupie [ateistów]". ${ }^{19}$

To niefortunne, że wielu chrześcijan nie potrafi odróżnić nauki od przekonania towarzyszącego. Thomas Nagel — deklarujący się jako ateista - rozpętał ostatnio burzę protestów w ,świeckim establishmencie teoretycznym i współczesnej oświeconej kulturze, którą zdominował", gdyż zauważył, że ów establishment jest ponad wszystko wierny „dominującemu naturalizmowi naukowemu, silnie zależnemu od darwinowskich wyjaśnień praktycznie wszystkiego, i uzbrojony po zęby przeciwko atakom ze strony religii". ${ }^{20}$

\footnotetext{
${ }^{19} \mathrm{http}: / / \mathrm{www} \cdot$ beliefnet.com/columnists/scienceandthesacred/2009/08/why-i-think-the-new-at heists-are-a-bloody-disaster.html (11.09.2016).

${ }^{20}$ Por. Thomas NAGEL, Mind and Cosmos: Why the Materialist Neo-Darwinian Conception of Nature Is Almost Certainly False, Oxford University Press, Oxford 2012.
} 


\section{Krok 4: Naukowcy oddzielają przekonania towarzyszące od teorii}

Przykłady opisane powyżej koncentrują się na logicznych aspektach związków między przekonaniami towarzyszącymi a wyjaśnieniami w nauce. Pokazują, że z logicznego punktu widzenia można je rozłączyć dzięki zmianie założeń uszczegóławiających. Ten luźny charakter powiązania przekonania towarzyszącego i wyjaśnienia zachodzi również w przypadku pracy naukowców na poziomie personalnym, co pokażę za pomocą dwu zbiorów przykładów.

Po pierwsze, jednym z powodów, dla których nie należy się martwić o możliwość zniekształcenia przez przekonania towarzyszące, jest zjawisko wielokrotnych niezależnych odkryć. Na przykład w starożytnej kulturze chińskiej niedostatek źródeł pisanych sprawiał, że matematycy często odkrywali lub wynajdywali na nowo wcześniejsze osiągnięcia. ${ }^{21} \mathrm{~W}$ Europie Zachodniej Mendlowskie prawa genetyki zostały niezależnie na nowo odkryte w 1903 roku przez trzech genetyków. Jest to analogiczne do sytuacji, w której czterech sprawozdawców potwierdza to samo zdarzenie. Najwyraźniej treść takich sprawozdań lub odkryć nie jest zależna od przekonań towarzyszących odkrywcy. Zjawisko wielokrotnych niezależnych odkryć wyklucza potencjalne zniekształcenie przez przekonania towarzyszące na poziomie indywidualnym.

Odkrywanie tej samej matematycznej i naukowej wiedzy w różnych i odizolowanych kulturach wyklucza zniekształcenie przez wspólne przekonania towarzyszące utrzymywane na przykład w ramach programów badawczych lub w szkołach myślenia. Przykładowo wiedza matematyczna odkryta niezależnie w Europie Zachodniej i starożytnych Chinach obejmuje twierdzenie dwumianowe, rozwiązanie n-tych pierwiastków i równań wielomianowych za pomocą metody Hornera, najwcześniejsze zastosowanie liczb ujemnych, analizę kombinatoryczną, Gaussowską metodę eliminacji mającą zastosowanie do rozwiązywania układów równań liniowych, rozwiązania równań nieokreślonych liczb całkowitych, algebrę z ciągami nieskończonymi i metody interpolacji różnic skończo-

\footnotetext{
${ }^{21}$ Por. Harro VAn BRummelen, „Mathematical Truth: A Cultural Study”, w: R.W. Howell and W.J. Bradley (eds.), Mathematics in a Postmodern Age: A Christian Perspective, Eerdmans, Grand Rapids, Michigan 2001, s. 45-64.
} 
nych. ${ }^{22}$ Ponadto w fizyce pierwsze prawo Newtona (prawo bezwładności) najwyraźniej przyszło do głowy niezależnie kilku różnym filozofom przyrody i naukowcom. Bezwładność ruchu opisał w trzecim wieku p.n.e. chiński filozof Mo Tzu, zaś w wieku jedenastym zrobili to muzułmańscy fizycy Alhazen ${ }^{23}$ i Awicenna. ${ }^{24}$ Siedemnastowieczny filozof René Descartes także sformułował to prawo, chociaż nie przeprowadził żadnych eksperymentów w celu jego potwierdzenia. ${ }^{25}$ Tych uczonych dzieli wiele setek lat, a także bardzo różne wartości kulturowe. Nie mogli oni podzielać przekonań towarzyszących, które mogłyby wyjaśnić to, że dokonali tego samego odkrycia.

Powróćmy do zniekształcającej roli przekonań towarzyszących utrzymywanych przez poszczególne osoby. Drugi zbiór przykładów dotyczy historii rasizmu, która powiązana jest z interakcjami między społeczeństwem a genetyką. Skupię się na społecznych i indywidualnych przekonaniach towarzyszących genetyków Karla Pearsona (1857-1936), Ronalda Fishera (1890-1962) i Johna Haldane'a (1892-1964). Opierali się oni pokusie dopuszczenia, by ich osobiste przekonania towarzyszące zniekształciły wiedzę naukową.

Pearson jest twórcą współczesnej statystyki. Wykazano, że jego statystyczne podejście do ludzkiej genetyki było motywowane problemami biologicznymi, nie zaś ideologią eugeniki, której był gorącym zwolennikiem. Fisher jest twórcą genetyki populacyjnej. Pokazał, jak trudno byłoby wyeliminować szkodliwe geny z ludzkiej populacji, pomimo że jest to ideał ruchu eugenicznego, który popierał. Wreszcie, Haldane rozwinął ważne części teorii doboru naturalnego, pomimo swej podejrzliwości względem ruchu eugenicznego, który chciał wyko-

\footnotetext{
${ }^{22}$ Por. Van Brummelen, „Mathematical Truth...”.

${ }^{23}$ Por. Abdus SAlam, „Islam and Science”, w: C.H. LaI (ed.), Ideals and Realities: Selected Essays of Abdus Salam, 2nd ed., World Scientific, Singapore 1987, s. 179-213, http://www.glob alwebpost.com/farooqm/study_res/abdus_salam/i_science.html.

${ }^{24}$ Por. Fernando EspinozA, „An Analysis of the Historical Development of Ideas about Motion and Its Implications for Teaching”, Physics Education 2005, vol. 40, no. 2, s. 141 [139-146], http://tiny.pl/gcszj (11.09. 2016).

${ }^{25}$ Por. René Descartes, Zasady filozofii, przeł. Izydora Dąmbska, wyd. 2, Biblioteka Europejska, Antyk, Kęty 2001, §§36-39.
} 
rzystać dobór sztuczny do oczyszczenia ludzkiej rasy. ${ }^{26}$

Ci uczeni nie dopuścili, by ich praca w dziedzinie genetyki została zniekształcona przez ich przekonania towarzyszące, mimo że były one wzajemnie sprzeczne. „Ideologia eugeniki nie determinuje rodzaju nauki o charakterystycznej, zorientowanej eugenicznie treści". ${ }^{27}$ Ważne są tutaj dwie kwestie: teoria ewolucji biologicznej nie determinuje teorii lub praktyk eugenicznych; teoria nie jest zła tylko dlatego, że jacyś ideolodzy nadużywają jej dla swoich niecnych celów. Taki wniosek byłby równie nieuzasadniony, jak uznanie, że Internet jest zły, ponieważ terroryści publikują w nim przepisy na produkcję bomb. Stanie się to jeszcze oczywistsze, jeśli weźmiemy pod uwagę, że teoria ewolucji biologicznej w istocie działa na niekorzyść rasizmu na przynajmniej dwa sposoby. Po pierwsze, genetyczna teoria doboru naturalnego podważyła ideę, że równoległa ewolucja różnych ras ludzkich wytworzyłaby lub wytworzyła różne gatunki ludzkie. Uczyniła to dzięki wykazaniu, że rasy nie były odseparowane od siebie dostatecznie długo, by stać się różnymi gatunkami ludzkimi. Po drugie, genetyczna teoria doboru naturalnego podkreśla genetyczną jedność wszystkich ludzi, wskazując, że mają oni wspólnego przodka. W ten sposób przemawia ona przeciwko dyskryminacji rasowej.

Do tej pory argumentowałem, że chrześcijanin ma obowiązek eliminowania zniekształceń powodowanych przez przekonania towarzyszące z wyjaśnień naukowych, że wspólnotowy charakter badań naukowych pomaga chronić przed takimi zniekształceniami, że eliminacja zniekształceń jest możliwa z logicznego punktu widzenia i że naukowcy formułowali wyjaśnienia i teorie niezgodne $\mathrm{z}$ ich osobistymi przekonaniami towarzyszącymi. Zniekształcenie jest niczym wykolejenie normalnej i zwykle konstruktywnej roli przekonań towarzyszących. Jaka jest ta konstruktywna rola i jak przekonania towarzyszące mogą ją pełnić, nie skłaniając do relatywizmu?

\footnotetext{
${ }^{26}$ Por. Peter J. Bowler and Ivan R. Morus, Making Modern Science, University of Chicago Press, Chicago 2005, s. 433-434.

${ }^{27}$ Dziękuję jednemu z recenzentów za zasugerowanie tego zdania.
} 


\section{Krok 5: Konstruktywna rola przekonań towarzyszących}

W normalnych warunkach przekonania towarzyszące pomagają formułować teorie i wyjaśnienia naukowe. Teoria naukowa wykracza poza dane - w przeciwnym razie niczego nie mogłaby wyjaśnić. ${ }^{28}$ Przekonania towarzyszące mają udział w tej części teorii, która wykracza poza dane. Naukowcy mają swobodę wyboru dowolnego odpowiadającego im przekonania towarzyszącego z ich kontekstu społecznego i kulturowego. Weźmy na przykład kosmologię heliocentryczną Galileusza, która wskazywała, że pływy mogą być skutkiem dziennego i rocznego ruchu Ziemi. Wpadł na pomysł tej teorii pewnego dnia, gdy obserwował ruch wody w gondoli w Wenecji. Gdy gondola poruszała się do przodu, woda przepływała do tyłu, narastając przy rufie. Galileusz sądził, że pływy mogą być wodą piętrzącą się w skali globu.

Wyobraźmy sobie Ziemię okrążającą Słońce po swojej orbicie raz na rok. ${ }^{29}$ Jednocześnie Ziemia obraca się codziennie wokół własnej osi w kierunku przeciwnym do ruchu wskazówek zegara. W wyobraźni narysujmy teraz linię łączącą środek Słońca ze środkiem Ziemi. Linia ta przecina obwód Ziemi w dwóch punktach: jednym bliżej Słońca (A) i drugim dalej od Słońca (B). W punkcie (A) kierunek orbity Ziemi dokoła Słońca pokrywa się z kierunkiem jej rotacji osiowej. Mając na uwadze dwa wzmacniające się wzajemnie ruchy, Galileusz rozumował, że woda $\mathrm{w}$ oceanach będzie narastać na drugim końcu Ziemi, tak jak w przypadku gondoli: przypływ. W punkcie (B) dwa ruchy zachodziłyby w przeciwnych kierunkach, jeden wygaszałby drugi, przez co woda by się nie nagromadzała. Woda przepływałaby w drugą stronę: odpływ. Teoria ta opierała się na przekonaniu towarzyszącym oraz na doświadczeniu z życia codziennego w Wenecji.

Rozważmy teraz implikacje tej teorii. Na przykład Ziemia obraca się wokół własnej osi w ciągu 24 godzin. Galileuszowy przypływ przemieszcza się więc wokół globu w 24 godziny, podobnie jak odpływ. Jednak każdy mieszkający

\footnotetext{
${ }^{28}$ Więcej szczegółów por. w: Jitse M. van DER MeER, „Progress in Nature and Culture: How Biology Can Have the Best of Both Worlds” [recenzja książki: Michael Ruse, Monad to Man], Biology and Philosophy 2000, vol. 15, s. 759-772.

${ }^{29}$ Por. http://www.pbs.org/wgbh/nova/galileo/mistake.html (11.09.2016).
} 
niedaleko morza wie, że codziennie następują dwa przypływy. Przekonanie towarzyszące nie uzyskało potwierdzenia obserwacyjnego i należy je zastąpić.

Napisałem, że naukowcy mogą swobodnie korzystać z dowolnego dogodnego dla nich przekonania towarzyszącego, ale na tym ta wolność się kończy. Przy budowaniu teorii potwierdzenie ze strony przekonania towarzyszącego może stać się trwałe tylko wówczas, jeśli to przekonanie koresponduje z obserwacjami $\mathrm{i}$ innymi dobrze ugruntowanymi teoriami. Jedynie wtedy racjonalna i uzasadniona jest akceptacja przekonania towarzyszącego jako wiedzy naukowej. Dlatego przekonania towarzyszące niekoniecznie zniekształcają wiedzę naukową, czyniąc z niej zbiór arbitralnych opinii (subiektywizm). Nie sprawiają też, że naukowa wiedza o przyrodzie jest niemożliwa (relatywizm). Ilustruje to dalsza historia teorii pływów, która doprowadziła do teorii, którą akceptujemy obecnie.

Naukowcy powinni konstruować teorie możliwie najbardziej korespondujące z obiektywnie istniejącą rzeczywistością. Jeżeli jakieś przekonanie towarzyszące nie uzyskuje statusu wiedzy naukowej, to musi być skonkretyzowane przez inne założenie uszczegóławiające lub ustąpić miejsca lepszej alternatywie. Jeśli się to nie uda, będzie to jedna z przyczyn ewentualnej zmiany konstruktywnej roli przekonania towarzyszącego w rolę destruktywną, która prowadzi do zniekształcenia prawdy. Przekształcenie otwartej heurystyki względem wyjaśnień w zamkniętą dogmatykę może zachodzić stopniowo, jak pokazuje przypadek Galileusza. Naukowcy są ludźmi i niechętnie odrzucają wyniki swojej pracy. Istnieje wiele możliwych powodów tej niechęci. Przyjrzyjmy się przykładowi.

Galileusz i jemu współcześni mieli świadomość, że jego teoria pływów ma wady, ponieważ w Wenecji codziennie następuje nie jeden przypływ, lecz dwa - co około dwanaście godzin. Galileusz ignorował tę anomalię, uznając ją za skutek różnych drugorzędnych przyczyn, jak kształt morza, jego głębokość i inne czynniki. ${ }^{30}$ Chociaż były to prawomocne powody, aby utrzymać tę teorię, Galileusz miał powód znacznie poważniejszy. Jego teoria wyjaśniała pływy jako

\footnotetext{
${ }^{30}$ Por. Maurice A. Finocchiaro, The Galileo Affair: A Documentary History, University of California Press, Berkeley, California 1989, s. 127-131; Galileusz, Dialog o dwu najważniejszych układach świata: ptolemeuszowym i kopernikowym, przeł. Edward Ligocki, Arcydzieła Wielkich Myślicieli, Ediciones Altaya Polska \& De Agostini Polska, Warszawa 2004, s. 661-666.
} 
skutek dziennego i rocznego ruchu Ziemi. Gdyby teoria pływów okazała się prawdziwa, stanowiłaby świadectwo na rzecz jego teorii układu planetarnego, w którego środku znajduje się Słońce. Ta ostatnia była największym osiągnięciem w karierze Galileusza, a także przyczyną jego konfliktu z kościołem. Stawka była wysoka. W ostateczności osobiste i społeczne interesy nie miały znaczenia. Obserwacje ukształtowały wiedzę o pływach, jaką posiadamy dzisiaj. Już za życia Galileusza jego kolega, astronom Kepler, zasugerował, że Księżyc jest jedną z przyczyn pływów, co współcześnie stanowi część wyjaśnienia. ${ }^{31}$ Pokazuje to, jak wspólnotowy charakter badań naukowych eliminuje osobiste preferencje.

Gdy przyglądamy się historii teorii, takiej jak teoria pływów, dostrzegamy, że zdobywanie przez naukę poparcia kulturowego może przebiegać cyklicznie. Kiedy teoria musi zostać zrekonstruowana, wymagane może być nowe przekonanie towarzyszące. Dlatego przekonania towarzyszące muszą być zastępowalne. Nie można utrzymywać ich dogmatycznie, ponieważ - w tej lub innej chwili - zaczną zniekształcać wiedzę naukową.

Rodzaj przekonań towarzyszących mających zapewniać poparcie danej teorii zależny jest od lokalnych okoliczności kulturowych i historycznych. We współczesnych pluralistycznych społeczeństwach zachodnich poparcie dla przekonań towarzyszących płynie również z wielu innych źródeł. Od wieków średnich po wczesną nowożytność religia chrześcijańska stanowiła oczywiste źródło przekonań towarzyszących, ponieważ kultura europejska była w przeważającej mierze chrześcijańska. W naszych czasach źródło to jest nadal oczywiste, ale dla poszczególnych chrześcijan. Rodzi to pewne pytanie. Napisałem, że przekonanie towarzyszące musi być skonkretyzowane przez różne założenia uszczegóławiające lub ustąpić miejsca lepszej alternatywie, o ile nie wejdzie w skład wiedzy naukowej. Jeżeli to przekonanie jest jednym z fundamentalnych przekonań wiary chrześcijańskiej, to czy nie implikowałoby to, że chrześcijanin powinien być gotów żyć i umierać za jakieś zwykłe przekonanie towarzyszące tak samo jak jest zobowiązany żyć i umierać za swego Zbawiciela i Pana? Z drugiej strony, czy nie implikowałoby to, że chrześcijanin powinien być przygotowany do

\footnotetext{
${ }^{31}$ Wyjaśnienie pływów można znaleźć na stronie: http://www.sjsu.edu/faculty/watkins/tides. htm (11.09.2016).
} 
zastąpienia jednego z fundamentalnych przekonań chrześcijańskich wraz z innymi niepożądanymi przekonaniami towarzyszącymi, kiedy jest to konieczne?

Obie powyższe implikacje są błędne, ponieważ nie odróżniają ograniczonej funkcji przekonań towarzyszących w rozumowaniu naukowym od związku $\mathrm{z}$ osobą - w tym wypadku z osobą Jezusa Chrystusa. To oczywiście prawda, że chrześcijanin może utracić wiarę. Powodem tego niemal zawsze są jednak osobiste doświadczenia. Każdy osobowy związek ma znacznie szerszą podstawę niż racjonalne zobowiązanie wobec przekonania towarzyszącego, mimo że to ostatnie stanowi część tej podstawy. Chrześcijańskie przekonanie towarzyszące, na przykład to, że Bóg jest Stwórcą wszystkiego, co istnieje, ma tę szerszą podstawę, ponieważ jest wbudowane w taki osobowy związek.

Dzięki tej podstawie każde specyficznie chrześcijańskie przekonanie towarzyszące ma szerokie spektrum funkcji. Gdy chrześcijanin wykorzystuje takie przekonanie w argumentacji naukowej, szerokie spektrum jego funkcji jest tak dostosowywane, że dominuje jego funkcja intelektualna. ${ }^{32}$ Tę intelektualną funkcję można zmienić, nie wpływając na całe spektrum funkcji. Poza tym funkcja intelektualna może nie wymagać zmiany, ponieważ można zastąpić hipotezę uszczegóławiającą, która łączy przekonanie towarzyszące z wyjaśnieniem naukowym. Czasem potrzeba ponownego rozważenia specyficznie chrześcijańskiego przekonania towarzyszącego może jednak prowadzić do utraty wiary. Powodem tego może być opuszczenie pola gry między osobistym związkiem z Jezusem Chrystusem a przekonaniami towarzyszącymi, które funkcjonują w nauce. Skutkuje to zredukowaniem związku personalnego do związku czysto racjonalnego. Problem leży wówczas w tym zredukowanym związku, nie zaś w nauce.

W nauce niedopuszczalne są nie tylko przekonania towarzyszące funkcjonujące dogmatycznie. Bóg również nie może stanowić elementu wyjaśnień naukowych. Jest tak po części dlatego, że twierdzenie, zgodnie z którym Bóg stworzył

\footnotetext{
${ }^{32}$ Por. Jitse M. van der MeER, „The Actor in the Interaction of Science and Religion: An Application of Dooyeweerd's Anthropology to the Study of Religion and Science Relations", w: The Collected Works of Herman Dooyeweerd Series C-Dooyeweerd's Living Legacy, vol. 1: Contemporary Reflections on the Philosophy of Herman Dooyeweerd, ed. D.F.M. Strauss, The Edwin Mellen Press, Lewiston, New York 2000, s. 183-194.
} 
na przykład wulkany, choć prawdziwe, nie wyjaśniałoby, gdzie wulkany się znajdują lub dlaczego wybuchają. Cel wyjaśnień naukowych jest ograniczony — poszukiwanie przyczyn materialnych na podstawie doświadczenia — a Bóg po prostu nie jest materialną przyczyną, gdyż byłby wówczas stworzeniem. Tymczasem Bóg jest Stwórcą wszystkich przyczyn materialnych. Naukowiec jest więc jak rolnik, o którym mowa w Iz 28:23-29, dla którego uczenie się z doświadczenia jest tym samym, co otrzymywanie wiedzy od Pana. Co więcej, gdyby Bóg był elementem wyjaśnienia, oznaczałoby to, że byłby traktowany jako zmienna, którą eksperymentator może manipulować. Takie potraktowanie Boga byłoby w moim przekonaniu bluźnierstwem, a tym samym byłoby absolutnie niemożliwe do przyjęcia z perspektywy chrześcijańskiej. Wreszcie, czyż wyjaśnianie materialnych zjawisk za pomocą materialnych przyczyn nie jest właściwe, skoro Bóg stworzył je z materii?

\section{Krok 6: Autodestrukcyjne przekonania towarzyszące}

Jak dotąd, argumentowałem, że przekonania towarzyszące są wymagane do formułowania wyjaśnień naukowych i że jedne od drugich można logicznie odłączyć. W grę wchodzą jednak nie tylko logiczne związki między przekonaniami towarzyszącymi a nauką.

Mary Hesse zaobserwowała, że:

Ci (jak filozofowie), których interesuje logika i argumentacja, mają zbyt dużą skłonność do niedostrzegania tego, że mogą istnieć bardzo ważne tendencje i podobieństwa pomiędzy ideami, które nie podlegają ścisłemu wynikaniu, ale które okazują się po namyśle wysoce wpływowe i od których nie da się łatwo uwolnić przez wzgląd na to, że nie są logicznie konkluzywne. Powinniśmy dokładnie przyglądać się tym tendencjom, aby przekonać się, czy warto szukać powodów do ich przyjęcia i w jakim stopniu należy się im przeciwstawiać. ${ }^{33}$

Hesse poczyniła tę obserwację w odniesieniu do redukcjonizmu. Redukcja czy redeskrypcja rzeczywistości, argumentowała Hesse, może stanowić prawo-

\footnotetext{
${ }^{33}$ Mary Hesse, „Reductionism in the Sciences: Some Reflections on Part I”, w: Arthur PeAсосKe (ed.), Reductionism in Academic Disciplines, The Higher Education Foundation, Guildford, Surrey 1985, s. 108 [105-112].
} 
mocną część odkrycia. Na przykład religię i moralność można opisać jako zjawiska społeczne lub biologiczne. Może to być konstruktywne, o ile społeczna lub biologiczna redeskrypcja ma mieć znaczenie heurystyczne i otwierać umysł na inne aspekty religii i moralności. Ta sama redeskrypcja może jednak być destruktywna, jeżeli oferowana jest dogmatycznie jako pełna charakterystyka religii i moralności. Innymi słowy, chociaż przekonania towarzyszące pełnią funkcję logiczną $\mathrm{w}$ argumentacji, to mogą też przyjmować funkcję dogmatyczną.

Argumentowałem, że przekonania towarzyszące funkcjonują na różnych poziomach ogólności. Teraz dodałem, że na każdym poziomie mogą pełnić funkcję heurystyczną lub dogmatyczną. W naszym przykładzie każde przekonanie towarzyszące funkcjonowałoby dogmatycznie, gdyby przeczyło realności innych aspektów religii i moralności niż aspekty społeczne i biologiczne. W ten sposób konstruktywna funkcja przekonania towarzyszącego może przejść w funkcję dogmatyczną, gdy staje się sztywną dogmatyczną ideologią. Sądzę, że to właśnie miał na myśli Abraham Kuyper, gdy mówił o antytezie między „dwoma państwami” Augustyna - chrześcijaństwem i światem. Wskazywał on na ideologiczne funkcjonowanie przekonań towarzyszących głównie na wyższym poziomie ogólności, bardzo oddalonym od obserwacji i teorii.

Wskazywałem też, że przekonania towarzyszące na każdym poziomie ogólności można oddzielić od skojarzonych $\mathrm{z}$ nimi teorii dzięki zmianie założeń uszczegóławiających. Rodzi się pytanie, czy dogmatyczne nastawienie, z jakim można utrzymywać przekonania towarzyszące, nie sprawia, że ta możliwość staje się trywialna. Nie uważam tak, ponieważ ideologie da się oddzielić od teorii na inne sposoby niż zmiana założeń uszczegóławiających. Aby potwierdzić tę tezę, posłużę się dwoma dobrze znanymi przykładami takich ideologii: naturalizmem i empiryzmem.

Naturalizm to pogląd, zgodnie z którym przyroda jest wszystkim, co istnieje, a na wiedzę składają się wyjaśnienia odwołujące się do przyczyn naturalnych. Przykład ten koncentruje się na redukcji umysłu do materii. Karol Darwin najprawdopodobniej jako pierwszy zauważył problem nazywany obecnie „wątpliwością Darwina":

Zawsze pojawia się u mnie straszna wątpliwość, czy przekonania ludzkiego umysłu, który rozwinął się z umysłu zwierząt niższych, mają jakąkolwiek wartość lub czy moż- 
na im w ogóle zawierzyć. Czy ktokolwiek ufałby przekonaniom umysłu małpy, jeżeli są w nim jakieś przekonania? ${ }^{34}$

Alvin Plantinga, w swoim szczegółowym omówieniu dokonanej przez Darwina redukcji umysłu do fizyki, argumentuje, że wiara w teorię ewolucji jest irracjonalna, ponieważ teoria ta zaprzecza, że ludzie mogą mieć wiarygodne, prawdziwe przekonania o rzeczywistości. ${ }^{35}$

Takie same argumenty wysuwano względem naturalizmu określanego mianem materializmu. J.B.S. Haldane był autorem jednej z najbardziej zwięzłych interpretacji:

Jeżeli moje procesy umysłowe są $\mathrm{w}$ pełni zdeterminowane przez ruchy atomów w moim mózgu, to nie mam podstaw uważać, że moje przekonania są prawdziwe [...] a tym samym nie mam powodu sądzić, że mój mózg składa się z atomów. ${ }^{36}$

Jak wyraził się Erwin Strauss: „Fizyka odrzuca fizykalizm”. ${ }^{37}$ Marjorie Grene wyjaśnia:

Jeśli istnieje jakakolwiek wiedza, wliczając w to — gdyby było to możliwe - „wiedzę", że nie istnieje nic poza materialnymi cząstkami w ruchu, to musi istnieć coś więcej niż materialne cząstki w ruchu, mianowicie coś, przez co nie mam na myśli jakiejś „,zzeczy”, lecz pewien proces, jakiś realny byt, który może sformułować kompetentne, o ile nie prawdziwe, twierdzenie, że tak jest. Jednak molekuły nie formułują twierdzeń prawdziwościowych i nie mogą też popełnić błędu. Jeżeli więc istnieje jakakolwiek wiedza, nawet „nauka molekularna”, to istnieje coś więcej niż przedmiot nauki molekularnej. Są przynajmniej naukowcy molekularni. Innymi słowy, albo żadna wiedza

\footnotetext{
${ }^{34}$ Charles Darwin, list do W. Grahama z 3 lipca 1881 roku, w: Francis Darwin (ed.), The Life and Letters of Charles Darwin, vol. 1, Elibron, Boston 2005 (1887), s. 285.

${ }^{35}$ Por. Alvin Plantinga, Warrant and Proper Function, Oxford University Press, New York 1993, rozdz. 11-12, http://www.calvin.edu/academic/philosophy/virtual_library/articles/plantinga _alvin/naturalism_defeated.pdf (26.09.2016).

${ }^{36}$ J.B.S. Haldane, Possible Worlds: And Other Essays, Chatto and Windus, London 1927 (reprint 1932), s. 209.

${ }^{37}$ Erwin Strauss, The Primary World of Senses, Free Press of Glencoe, New York 1963, s. $298-304$
} 
nie istnieje (w tym wiedza o atomizmie filozoficznym), albo istnieje przynajmniej wiedza, że atomizm filozoficzny jest fałszywy. ${ }^{38}$

Grene otwarcie przyznaje, że „ontologia jednopoziomowa jest wewnętrznie sprzeczna". ${ }^{39}$ Wewnętrzna sprzeczność służy jej jako kryterium identyfikowania dwóch poziomów.

Wreszcie, Polanyi sformułował tego typu argument, krytykując mechanistyczne spojrzenie na organizmy. Według niego biologowie są w błędzie, twierdząc, że mechanistyczne wyjaśnienie organizmów to wyjaśnienie powołujące się na prawa fizyki i chemii. Błąd - wskazywał Polanyi — polega na tym, że zasad działania maszyny nie da się wyjaśnić przez odwołanie do praw fizyki i chemii, lecz wymaga to odniesienia do zasad projektowych zapewnianych przez inżynierów, którzy nadają maszynie cel. ${ }^{40}$ Konkludując, zaprzeczanie istnieniu bytów innych niż materia prowadzi do wewnętrznej sprzeczności. Wewnętrznej sprzeczności można uniknąć, uznając istnienie tych innych bytów $z$ ich własnymi nieredukowalnymi prawami. To dobry powód do odrzucenia ideologicznej funkcji, jaką może przyjąć przekonanie towarzyszące przez wzgląd na dogmatyczne cele tego, kto to przekonanie żywi. Otwarta jest więc możliwość odłączenia przekonań towarzyszących od teorii. Dooyeweerd wysunął ideę unikania wewnętrznej sprzeczności jako ogólnej strategii odróżniania różnych rodzajów praw we Wszechświecie. ${ }^{41}$

Empiryzm to pogląd, według którego doświadczenie zmysłowe stanowi ostateczne źródło całej wiedzy. Wiedza o przyrodzie nie może pochodzić z wizji, halucynacji czy też samej refleksji. Dobrze znany problem indukcji pozwala zilustrować autodestrukcyjny charakter empiryzmu. Jak przekonywał Hume, ab-

\footnotetext{
${ }^{38}$ Marjorie Grene, „Biology and the Problem of Levels of Reality”, The New Scholasticism 1967, vol. 41, s. 94-123, przedruk w: Marjorie Grene, The Understanding of Nature: Essays in the Philosophy of Biology, Boston Studies in the Philosophy of Science, vol. 23, Reidel, Boston, Massachusetts 1974, s. 42.

${ }^{39}$ Grene, The Understanding of Nature..., s. 44.

${ }^{40}$ Por. Michael Polany, The Tacit Dimension, Doubleday \& Company, Garden City, New York 1966, s. 38.

${ }^{41}$ Por. Herman Dooyeweerd, A New Critique of Theoretical Thought, vol. 2, The Presbyterian and Reformed Publishing, Nutley, New Jersey 1969, s. 38-41.
} 
solutnej prawdy i uniwersalnej prawomocności wiedzy empirycznej nie da się udowodnić na drodze doświadczenia, ponieważ doświadczenie presuponuje to, co ma udowodnić. Według Hume'a, o tyle, o ile zasada jednorodności stanowi generalizację opartą na doświadczeniu, dotyczy jej problem indukcji: „Żadną więc miarą argumenty z doświadczenia czerpane nie mogą dowieść, że przyszłość będzie podobna do przeszłości, ponieważ wszystkie te argumenty opierają się na założeniu, że owo podobieństwo istnieje". ${ }^{42}$ Znaczy to, że doświadczenie jednorodności można uogólnić tylko wówczas, gdy prawdziwość uogólnienia nie ma charakteru absolutnego, lecz probabilistyczny. ${ }^{43}$ Wyjściem Hume'a była deklaracja, że oparte na doświadczeniu oczekiwanie, że te same przyczyny stowarzyszone są z tymi samymi skutkami, jest przyzwyczajeniem. Kant odpowiedział, że zasada jednorodności ma charakter metafizyczny. Przedefiniował on więc wiedzę jako produkt zarówno poznania zmysłowego, jak i umysłowego, natomiast Hume definiował ją jako rezultat wyłącznie poznania zmysłowego. Obie odpowiedzi odłączają dogmatyczną formę empiryzmu od teorii bez potrzeby zmiany założeń uszczegóławiających.

Problem indukcji pokazuje, że nauka również wymaga zdolności do argumentowania, co jest prawdą, a co fałszem. Tej zdolności nie może ustanowić sama nauka, ponieważ prawda i błąd to byty abstrakcyjne. Nie można postrzegać ich zmysłami. Patrząc z tej perspektywy, da się zauważyć, że nauka ma potrzeby, których nie może zaspokoić sama. Twierdzenia, że percepcja zmysłowa może zaspokoić te potrzeby, są autodestrukcyjne, tak jak w przypadku naturalizmu. Konsekwencją tego ograniczenia nauki jest to, że nie może ona uzyskać wiedzy o bytach niedostępnych zmysłom, takich jak wartości czy Bóg. Wielu jednak ignoruje to ograniczenie. Jedną $z$ takich wartości jest pogląd, że percepcja zmysłowa to jedyna zasadna droga zdobywania wiedzy. Inni utrzymują, że jeśli Boga można poznać, to tylko drogą doświadczenia zmysłowego. Może wydawać się to zaskakujące, ale oto jak ujmuje te sprawę kontrowersyjny teolog protestancki H.M. Kuitert (ur. 1924): wszystko, czego można dowiedzieć się o Bogu, uzyskuje się oddolnie przez doświadczenie, nie zaś odgórnie drogą ob-

\footnotetext{
${ }^{42}$ Dawid Hume, Badania dotyczące rozumu ludzkiego, przeł. Jan Łukasiewicz i Kazimierz Twardowski, Arcydzieła Wielkich Myślicieli, Ediciones Altaya Polska \& De Agostini Polska, Warszawa 2001, s. 41-42.

${ }^{43}$ Por. Hume, Badania dotyczące rozumu ludzkiego..., s. 36-42.
} 
jawienia. Jest to przykład tego, jak jeden rodzaj wiedzy — wiedzy empirycznej — staje się standardem dla całej wiedzy (empiryzm). Empiryzm zawodzi, ponieważ ignoruje inne drogi poznania, takie jak poznanie przez zaznajomienie się, poznanie przez bycie świadkiem, poznanie na mocy autorytetu, poznanie na drodze wiary, wiedza milcząca, samowiedza i wiedza z pamięci, które wszystkie mogą być równie prawdziwe. Podsumowując, problem z naturalizmem i empiryzmem polega na tym, że są wewnętrznie niespójne.

Ogólnie rzecz biorąc, istnieją dwa podstawowe nastawienia względem takich rodzajów przekonań towarzyszących wysokiego poziomu jak naturalizm i empiryzm. Są tacy, którzy postrzegają wiedzę naukową jako standard dla całej wiedzy - jest to zniekształcenie znane jako scjentyzm. Na przykład współodkrywca struktury DNA, Francis Crick, napisał, że „wiedza, którą już posiadamy, sprawia, że jest bardzo mało prawdopodobne, by istniało cokolwiek, czego nie wyjaśnią fizyka i chemia". ${ }^{44}$ Druga grupa, do której zalicza się autor niniejszego artykułu, uważa, że istnieją inne rodzaje wiedzy, i respektuje ograniczenia nauki. Australijski filozof nauki Alan Chalmers napisał:

Poza tym, co uznawane jest za wiedzę naukową, mamy codzienną wiedzę zdroworozsądkową, wiedzę, którą dysponują wprawni rzemieślnicy lub mądrzy politycy, wiedzę zawartą w encyklopediach lub gromadzoną w umyśle speca od teleturniejów i tak dalej. ${ }^{45}$

Ponadto brytyjska filozof Mary Midgley twierdzi, że

Nauka nie może być samowystarczalna. Nie możemy wierzyć w jej twierdzenia, nie wierząc najpierw w wiele innych zadziwiających rzeczy, takich jak istnienie zewnętrznego świata, wiarygodność naszych zmysłów, pamięć, informatorzy i prawomocność logiki. Jeżeli w te rzeczy wierzymy, to już w tym momencie otrzymujemy świat znacznie bogatszy niż ten, o którym mówi nauka. ${ }^{46}$

\footnotetext{
${ }^{44}$ Francis CRICK, Of Molecules and Men, University of Washington Press, Seattle, Washington 1966, s. 14, 98.

${ }^{45}$ Alan Chalmers, Science and Its Fabrication, Open University Press, Milton Keynes 1990, s. 25.

${ }^{46}$ Mary Midgley, Science as Salvation, Routledge, London 1992, s. 108.
} 
Taki sam pogląd wyraził ostatnio Thomas Nagel. ${ }^{47}$

Wskazywałem wcześniej, że istnieje małe prawdopodobieństwo, by uczeni należący do różnych naukowych tradycji badawczych żywili takie same przekonania towarzyszące. To samo można teraz odnieść do uczonych z różnych szkół myślenia w dziedzinie filozofii nauki. Panująca między nimi zgoda na to, że istnieją byty inne niż materia, pokazuje, że zniekształcenia powodowane przez przekonania towarzyszące można uznać za niezależne od tych przekonań. Taką zbieżność idei można postrzegać jako rezultat tego, że ta idea jest słuszna.

\section{Wnioski}

Moim punktem wyjścia było wskazanie, że uczeni wierzący w istnienie niezależnej od umysłu rzeczywistości mają moralny obowiązek przeciwstawiania się zniekształceniom ich wiedzy o zjawiskach przyrodniczych. Jest to możliwe, ponieważ nauka dysponuje standardowymi sposobami wykrywania zniekształceń wiedzy naukowej przez przekonania towarzyszące i ponieważ takie przekonania można odłączyć od wyjaśnień naukowych. Następnie pokazałem, że w swojej pracy naukowcy rzeczywiście przeciwstawiają się własnym przekonaniom towarzyszącym. W zasadzie praktykujący naukowcy to rozważni ludzie, którzy potrafią odróżnić właściwe i niewłaściwe zastosowanie przekonań towarzyszących. Rozumieją, że chociaż przekonania towarzyszące są wymagane do formułowania płodnych teorii naukowych, to takie przekonania mogą być utrzymywane dogmatycznie, co przekracza właściwe granice. Później zapytałem, czy dogmatyczne nastawienie, z jakim przekonania towarzyszące mogą być utrzymywane, nie sprawia, że swoboda odłączania takich przekonań na dowolnym poziomie ogólności od stowarzyszonych z nimi teorii poprzez zmianę założeń uszczegóławiających jest trywialna. Obierając naturalizm i empiryzm jako przykłady, argumentowałem za czymś przeciwnym - że ideologie są autodestrukcyjne i dlatego można je oddzielić od wyjaśnień bez zmiany założeń uszczegóławiających.

Różnica między właściwym a niewłaściwym zastosowaniem przekonań towarzyszących jest kwestią opinii. Takie opinie kształtowane są przez wpływy

${ }^{47}$ Por. Nagel, Mind and Cosmos.... 
kulturowe. Autorzy wykorzystywali tę sytuację do promowania różnych nienaukowych przedsięwzięć przystrojonych w autorytet nauki. Ogółowi ludzi trudno jest oddzielić ziarna od plew. Dotyczy to również chrześcijan, którzy błędnie uznali, że pojawianie się takich opinii stanowi okazję do odrzucenia niewygodnej — z perspektywy ich przekonań towarzyszących — wiedzy naukowej, tak jakby nie było obiektywnie istniejącego stworzonego świata, który jest odporny na zniekształcenia. Zamiast tego powinni oni zaangażować się w ocenę wiedzy naukowej w świetle odpowiednich faktów oraz ról przekonań towarzyszących, o ile jakieś mają. Niewłaściwe role przekonań towarzyszących można rozpoznać, gdy stają się one autodestrukcyjne.

Jednym z najnowszych przykładów wielu takich ocen jest książka Absence of Mind [Nieobecność umysłu] pióra Marylinne Robinson. ${ }^{48}$ To właśnie stanowisko krytycznego realizmu gwarantuje solidność samolotów, którymi latamy, umożliwia procedury medyczne, które pomagają nas leczyć, a także komputery, których używamy. Praktyczny sukces nauk przyrodniczych upewnia nas, że naukowcy mają kontakt z rzeczywistością oraz że ich wyjaśnienia i teorie niełatwo dają się zniekształcić przez ich przekonania towarzyszące. Chrześcijanie interpretują ten stan rzeczy jako rezultat obiektywnie istniejącej stworzonej rzeczywistości, która stawia opór zniekształceniom. Nikt nie jest w stanie uciec przed siłą tej rzeczywistości. Znaczy to, że chrześcijanie mogą współpracować z niechrześcijanami w ramach nauki. Gdy dochodzi do konfliktu między przekonaniami towarzyszącymi, mogą odwołać się do ograniczeń nałożonych przez obiektywną rzeczywistość na wiedzę naukową i/lub do ograniczeń samej wiedzy naukowej.

\section{Podziękowania}

Jestem wdzięczny za pomoc Arnoldowi Sikkemie, jak również za znakomite komentarze dwóch anonimowych recenzentów.

Jitse M. van der Meer

\footnotetext{
${ }^{48}$ Por. Marilynne Robinson, Absence of Mind: The Dispelling of Inwardness from the Modern Myth of the Self, Yale University Press, New Haven, Connecticut 2010.
} 


\section{Bibliografia}

Barbour Ian G., „Commentary on Theological Resources from the Physical Sciences”, $Z y$ gon 1966, vol. 1, s. 27-30.

BArbour Ian G., „Theology and Physics Forty Years Later”, Zygon 2005, vol. 40, s. 507512.

Bowler Peter J. and Morus Ivan R., Making Modern Science, University of Chicago Press, Chicago 2005.

Brooke John H., Science and Religion: Some Historical Perspectives, Cambridge University Press, Cambridge 1991.

Brooke John H., Osler Margaret J., and van der Meer Jitse M. (eds.), Science in Theistic Contexts: Cognitive Dimensions, University of Chicago Press, Chicago 2001.

Carson Hampton L., „Inversions in Hawaiian Drosophila”, w: Krimbas and Powell (eds.), Drosophila Inversion Polymorphism..., s. 407-439 (streszczenie tego tekstu: http://bio. illinoisstate.edu/kaedwar/HawaiianDrosophila/CarsonTree.htm).

Chalmers Alan, Science and Its Fabrication, Open University Press, Milton Keynes 1990.

CRICK Francis, Of Molecules and Men, University of Washington Press, Seattle, Washington 1966 .

Darwin Charles, list do W. Grahama z 3 lipca 1881 roku, w: DARwin (ed.), The Life and Letters of Charles Darwin..., s. 285.

DARwin Francis (ed.), The Life and Letters of Charles Darwin, vol. 1, Elibron, Boston 2005 (1887).

Descartes René, Zasady filozofii, przeł. Izydora Dąmbska, wyd. 2, Biblioteka Europejska, Antyk, Kęty 2001.

Dooyeweerd Herman, A New Critique of Theoretical Thought, vol. 2, The Presbyterian and Reformed Publishing, Nutley, New Jersey 1969.

Espinoza Fernando, „An Analysis of the Historical Development of Ideas about Motion and Its Implications for Teaching", Physics Education 2005, vol. 40, no. 2, s. 139-146, http:// tiny.pl/gcszj (11.09.2016).

Finocchiaro Maurice A., The Galileo Affair: A Documentary History, University of California Press, Berkeley, California 1989. 
FLECK Ludwik, Entstehung und Entwicklung einer wissenschaftlichen Tatsache. Einführung in die Lehre vom Denkstil und Denkkollektiv, Schwabe und Co., Verlagsbuchhandlung, Basel 1935.

FLECK Ludwik, Powstanie i rozwój faktu naukowego. Wprowadzenie do nauki o stylu myślowym i kolektywie myślowym, przeł. Maria Tuszkiewicz, w: FLECK, Psychosocjologia poznania naukowego..., s. 31-163.

FLECK Ludwik, Psychosocjologia poznania naukowego. Powstanie i rozwój faktu naukowego oraz inne pisma $z$ filozofii poznania, red. Zdzisław Cackowski i Stefan Symotiuk, Wydawnictwo Uniwersytetu Marii-Curie Skłodowskiej, Lublin 2006.

FLECK Ludwik, The Genesis and Development of a Scientific Fact, ed. T.J. Trenn and R.K. Merton, foreword by Thomas Kuhn, University of Chicago Press, Chicago 1979.

Foster Michael B., „The Christian Doctrine of Creation and the Rise of Modern Natural Science", Mind 1934, vol. 43, s. 446-448; 1935, vol. 44: 439-466; 1936, vol. 45, s. 1-27.

GALILEUSz, Dialog o dwu najważniejszych ukladach świata: ptolemeuszowym i kopernikowym, przeł. Edward Ligocki, Arcydzieła Wielkich Myślicieli, Ediciones Altaya Polska \& De Agostini Polska, Warszawa 2004.

Grene Marjorie, „Biology and the Problem of Levels of Reality”, The New Scholasticism 1967, vol. 41, s. 94-123.

Grene Marjorie, The Understanding of Nature: Essays in the Philosophy of Biology, Boston Studies in the Philosophy of Science, vol. 23, Reidel, Boston, Massachusetts 1974.

G.W. Leibniz: Philosophical Essays, trans. and ed. Roger Ariew and Dan Garber, Hackett, Indianapolis, Indiana 1989.

Haldane J.B.S., Possible Worlds: And Other Essays, Chatto and Windus, London 1927 (reprint 1932).

Harrison Peter, The Fall of Man and the Foundations of Science, Cambridge University Press, Cambridge 2007.

Hesse Mary, „Reductionism in the Sciences: Some Reflections on Part I”, w: Peacocke (ed.), Reductionism in Academic Disciplines..., s. 105-112.

Howell R.W. and Bradley W.J. (eds.), Mathematics in a Postmodern Age: A Christian Perspective, Eerdmans, Grand Rapids, Michigan 2001.

http://csep10.phys.utk.edu/astr161/lect/history/newtongrav.html. 
http://earthsci.org/education/teacher/basicgeol/platec/platec.html (07.09.2016).

http://en.wikipedia.org/wiki/Hawaiian_Islands (08.09.2016).

http://en.wikipedia.org/wiki/Plate_tectonics\#cite_ref-17 (07.09.2016).

http://tiny.pl/gcszn (08.09.2016).

http://news.cnet.com/8301-1023_3-10438960-93.html (07.09.2016).

http://www.beliefnet.com/columnists/scienceandthesacred/2009/08/why-i-think-the-new-at heists-are-a-bloody-disaster.html (11.09.2016).

http://www.pbs.org/wgbh/nova/galileo/mistake.html (11.09.2016).

http://www.physicalgeography.net/fundamentals/10i.html (07.09.2016).

http://www.sjsu.edu/faculty/watkins/tides.htm (11.09.2016).

http://www.visionlearning.com/library/module_viewer.php?mid=65 (07.09.2016).

Hume Dawid, Badania dotyczące rozumu ludzkiego, przeł. Jan Łukasiewicz i Kazimierz Twardowski, Arcydzieła Wielkich Myślicieli, Ediciones Altaya Polska \& De Agostini Polska, Warszawa 2001.

Krimbas C.B. and Powell J.R. (eds.), Drosophila Inversion Polymorphism, CRC Press, Boca Raton, Florida 1992.

KuHN Thomas S., Struktura rewolucji naukowych, przeł. Helena Ostromęcka i Justyna Nowotniak, Fundacja Aletheia, Warszawa 2001.

LeIBNIz Gottfried Wilhelm, „A New System of the Nature and Communication of Substances, and of the Union of the Soul and Body (1695)", w: G.W. Leibniz..., s. 138-145.

Losch Andreas, „On the Origins of Critical Realism”, Theology and Science 2009, vol. 7, s. $85-106$.

Midgley Mary, Science as Salvation, Routledge, London 1992.

Nagel Thomas, Mind and Cosmos: Why the Materialist Neo-Darwinian Conception of Nature Is Almost Certainly False, Oxford University Press, Oxford 2012.

O'Grady Patrick M. et al., „Polytene Chromosomes as Indicators of Phylogeny in Several Species Groups of Drosophila", BMC Evolutionary Biology 2001, vol. 1, s. 1-6, http:// www.biomedcentral.com/1471-2148/1/6 (08.09.2016). 
Peacocke Arthur (ed.), Reductionism in Academic Disciplines, The Higher Education Foundation, Guildford, Surrey 1985.

Plantinga Alvin, Warrant and Proper Function, Oxford University Press, New York 1993, http://www.calvin.edu/academic/philosophy/virtual_library/articles/plantinga_alvin/ naturalism_defeated.pdf (26.09.2016).

Polanyi Michael, Personal Knowledge: Towards a Post-Critical Philosophy, University of Chicago Press, Chicago 1958.

Polany Michael, The Tacit Dimension, Doubleday \& Company, Garden City, New York 1966.

Polkinghorne John, „The Metaphysics of Divine Action”, w: Russell, Murphy, and PeACOCKE (eds.), Chaos and Complexity..., s. 147-156.

RoBinson Marilynne, Absence of Mind: The Dispelling of Inwardness from the Modern Myth of the Self, Yale University Press, New Haven, Connecticut 2010.

Russell Robert John, Murphy Nancey, and Peacocke Arthur (eds.), Chaos and Complexity: Scientific Perspectives on Divine Action, Vatican Observatory Publications - The Center for Theology and Natural Sciences, Vatican City State - Berkeley, California 1997.

SALAm Abdus, „Islam and Science”, w: C.H. LAI (ed.), Ideals and Realities: Selected Essays of Abdus Salam, 2nd ed., World Scientific, Singapore 1987, s. 179-213, http://www. globalwebpost.com/farooqm/study_res/abdus_salam/i_science.html.

Strauss Erwin, The Primary World of Senses, Free Press of Glencoe, New York 1963.

The Collected Works of Herman Dooyeweerd Series C-Dooyeweerd's Living Legacy, vol. 1: Contemporary Reflections on the Philosophy of Herman Dooyeweerd, ed. D.F.M. Strauss, The Edwin Mellen Press, Lewiston, New York 2000.

Van Brummelen Harro, „Mathematical Truth: A Cultural Study”, w: R.W. Howell and W.J. Bradley (eds.), Mathematics in a Postmodern Age: A Christian Perspective, Eerdmans, Grand Rapids, Michigan 2001, s. 45-64.

van Der Meer Jitse M., „Progress in Nature and Culture: How Biology Can Have the Best of Both Worlds" [recenzja książki: Michael Ruse, Monad to Man], Biology and Philosophy 2000, vol. 15, s. 759-772. 
VAN DER MeER Jitse M., „The Actor in the Interaction of Science and Religion: An Application of Dooyeweerd's Anthropology to the Study of Religion and Science Relations", w: The Collected Works of Herman Dooyeweerd..., s. 183-194.

Wolfe Charles T., „Teleomechanism Redux?: Functional Physiology and Hybrid Models of Life in Early Modern Natural Philosophy”, Gesnerus 2014, vol. 71, no. 2, s. 290-307.

www.ceoe.udel.edu/deepsea/level-2/geology/vents.html.

\section{Przekonania towarzyszące, ideologia i nauka}

\section{Streszczenie}

Powszechny stał się pogląd, że nie tylko fakty, ale i osobiste oraz wspólne przekonania stanowią element wiedzy naukowej. Rodzi to dwa ważne pytania. Jak ludzie mający bardzo odmienne systemy przekonań mogą wspólnie uprawiać naukę? Czy wiedzy naukowej można ufać, skoro jest kształtowana i niekiedy zniekształcana przez przekonania funkcjonujące na zapleczu nauki? Zacznę od wskazania, że uczeni, którzy wierzą w istnienie rzeczywistości niezależnej od umysłu, mają moralny obowiązek przeciwstawiania się zniekształcaniu ich wiedzy o zjawiskach przyrodniczych. Następnie wyjaśniam, dlaczego przekonania towarzyszące są konieczne do formułowania teorii w nauce. Argumentuję, że przekonania towarzyszące niekoniecznie zniekształcają wiedzę naukową, ponieważ Bóg stworzył obiektywnie istniejącą rzeczywistość, która opiera się zniekształceniu. Gdy dochodzi do zniekształceń, nauka dysponuje standardowymi sposobami ich wykrywania. Sposoby te to między innymi zbieżność wzajemnie niezależnych linii danych empirycznych prowadzących do tego samego wyjaśnienia, możliwość odłączenia przekonań towarzyszących od wyjaśnień naukowych oraz autodestrukcyjność przekonań towarzyszących prowadzących do dogmatyzmu. Później pokazuję, że w swojej pracy naukowcy w istocie przeciwstawiają się własnym przekonaniom towarzyszącym. Zgodnie z moim wnioskiem przekonania towarzyszące naukowców nie dyktują treści wiedzy naukowej, zaś ludzie mający odmienne systemy przekonań, w tym chrześcijanie, mogą wspólnie prowadzić badania naukowe. Nie opowiadam się jednak za powrotem do chrześcijańskiej formy neopozytywizmu, ponieważ w pełni biorę pod uwagę to, czego dowiedzieliśmy się przez ostatnie kilkadziesiąt lat o tym, w jakim stopniu nauka osadzona jest w kontekście społeczno-kulturowym.

Slowa kluczowe: chrześcijaństwo, teizm, naturalizm, empiryzm, krytyczny realizm, relatywizm, założenie uszczegóławiające. 


\title{
Background Beliefs, Ideology, and Science
}

\begin{abstract}
Summary
The notion that not only facts but also personal and communal beliefs contribute to scientific knowledge has become commonplace. It raises two important questions. How can people with very different belief systems work together in science? Can scientific knowledge be trusted if it is shaped and sometimes distorted by beliefs operating in the background of science? I begin by pointing out that scholars who believe in the existence of a mind-independent reality have the moral calling to oppose distortion in their understanding of natural phenomena. I then explain why background beliefs are required for the construction of theories in science. I argue that background beliefs do not necessarily distort scientific knowledge because God created an objectively existing reality that resists distortion. When distortion occurs, science has standard ways of detecting that distortion. These include convergence of mutually independent lines of evidence on the same explanation, the possibility to disconnect background beliefs from scientific explanation, and the self-destruction of background beliefs that assume a dogmatic function. Next I show that in their work scientists, in fact, do sometimes oppose their personal background beliefs. The conclusion is that the background beliefs of scientists do not dictate the content of scientific knowledge, and that people with different belief systems, including Christians, can work together in scientific research. This is not to suggest a return to a Christian form of neopositivism because it fully incorporates what has been learned over the last decades about the extent to which science is embedded in a sociocultural context.
\end{abstract}

Keywords: Christianity, theism, naturalism, empiricism, critical realism, relativism, specifying assumption. 